\title{
ABSTENTIONS AND SOCIAL NETWORKS IN CONGRESS
}

\author{
Marco Battaglini \\ Valerio Leone Sciabolazza \\ Eleonora Patacchini \\ Working Paper 27822 \\ http://www.nber.org/papers/w27822
NATIONAL BUREAU OF ECONOMIC RESEARCH
1050 Massachusetts Avenue
Cambridge, MA 02138
September 2020

The views expressed herein are those of the authors and do not necessarily reflect the views of the National Bureau of Economic Research.

NBER working papers are circulated for discussion and comment purposes. They have not been peer-reviewed or been subject to the review by the NBER Board of Directors that accompanies official NBER publications.

(C) 2020 by Marco Battaglini, Valerio Leone Sciabolazza, and Eleonora Patacchini. All rights reserved. Short sections of text, not to exceed two paragraphs, may be quoted without explicit permission provided that full credit, including $\odot$ notice, is given to the source. 
Abstentions and Social Networks in Congress

Marco Battaglini, Valerio Leone Sciabolazza, and Eleonora Patacchini

NBER Working Paper No. 27822

September 2020

JEL No. D72,D74,D91

\section{ABSTRACT}

We study the extent to which personal connections among legislators influence abstentions in the U.S. Congress. Our analysis is conducted by observing representatives' abstention for the universe of roll call votes held on bills in the 109th-113th Congresses. Our results show that a legislator's propensity to abstain increases when the majority of his or her alumni connections abstains, even after controlling for other well-known predictors of abstention choices and a vast set of fixed effects. We further reveal that a legislator is more prone to abstain than to take sides when the demands from personal connections conflict with those of the legislator's party.

Marco Battaglini

Department of Economics

Uris Hall

Cornell University

Ithaca, NY 14850

and EIEF, CEPR

and also NBER

battaglini@cornell.edu

Valerio Leone Sciabolazza

Department of Economics

and Business

University of Naples Parthenope

Naples, Italy

valerio.leonesciabolazza@uniparthenope.it
Eleonora Patacchini

Department of Economics

Cornell University

430 Uris Hall

Ithaca, NY 14853

and CEPR

ep454@cornell.edu 
"Before one vote - on a measure about which Byrd did not have strong feelings but on which he would ordinarily have voted no-Johnson confided to a Senate aide that he might persuade him to abstain instead. "Harry Byrd is a man of principle, he said. "I can't ask Harry to do anything against his principles. But I can ask Harry Byrd-and may oblige me-to stay away [during the vote]."”1

\section{Introduction}

A long standing question in political economy is legislators' participation in roll call voting. There are many theories explaining politicians' turnout and abstention. None of them, however, considers the importance of personal social ties. A growing literature in political science and economics has provided causal evidence that the social networks of legislators have a major impact on their future political carrers and their legislative activities (see Battaglini and Patacchini [2019] for a recent review).

The goal of this paper is to determine whether and how the decision of a legislator to abstain is swayed by the behavior of his or her personal contacts. We examine participation on the universe of roll calls held on bills in the U.S. House of Representatives from 2005 to 2015 (i.e. from the 109th Congress (2005-2007) to the 113th Congress (2013-2015)). Following extant literature (Cohen and Malloy [2014], Battaglini and Patacchini [2018], Battaglini et al. [2020]), social connections are measured by looking at legislators' alumni connections: two Congress members are connected if they graduated from the same institution within a given time window. The advantage of this approach is that these connections cannot be the consequence of the behavior we attempt to explain.

To isolate the effect of personal contact from the influence of confounding factors, we assemble and hand-collect data from a variety of sources and use an empirical design based on a comprehensive set of control variables and fixed effects. In particular, we collect novel information on the identity of the party leaders during each roll call vote together with their voting behavior to identify the votes that are relevant to each party. Prior research (e.g., Rothenberg and Sanders $[1999,2000,2002])$ relies on the definition of key votes provided by the Congressional Quarterly Almanac (CQA). Such a categorization, however, have been often subject to criticism (Shull and Vanderleeuw [1987]), because it is not precise and votes salient to a given party are not always defined as key votes in all Congresses. We also use a novel definition of votes that are salient to a legislator's agenda by merging information on the legislator's sponsorship and cosponsorship activity with the content of the bill under vote. This is done by identifying the most recurrent policy issue in the bills sponsored or cosponsored

\footnotetext{
${ }^{1}$ Citation Ch. 19 ("Old Harry") p. 474 in Caro [2013] in which R. Caro discusses how Lyndon B. Johnson cultivated and used his personal relationship with Senator Harry Byrd of Virginia to advance his legislative projects.
} 
by a legislator, and then selecting the set of roll call votes in which this issue is discussed. Prior research instead defines vote salience by looking at the extent to which the economic activities of the legislator's district could be potentially affected by the outcome of the roll call vote. This was done by categorizing the content of a roll call vote as being related to a certain industry, and then assuming that the vote's outcome is relevant for the economy of the legislator's district if there is at least one firm in that industry in the district (Cohen and Noll [1991], Cohen and Malloy [2014]).

Our identification strategy relies primarily on the use of fixed effects for each legislator and roll call topic. Specifically, we are interested in the difference between a legislator's abstention behavior in a roll call vote on a specific topic when a given share of alumni connections abstain and that legislator's behavior in a roll call on the same topic if a different share of his or her alumni connections happen to abstain, controlling for roll call, Congress and time-varying individual characteristics.

Our results show that a legislator's propensity to abstain increases when the majority of his or her alumni connections choose to abstain. This finding is robust when conditioning on the party affilliations of the connected alumni and on the shared interests in law-making of connected legislators, as captured by their cosponsorship activity. In addition, because multiple roll call votes are held on the same bill, we are able to provide a model specification with bill fixed effects and to show that the estimated network effects are not determined by a specific predisposition of the legislator and his or her social connections toward the characteristics of the bill under vote.

A unique feature of our data and empirical design is that we are able to examine situations where network mechanisms may be responsible for a dissent from party lines. A literature in political science documents that facing divergent pressures when casting a vote may motivate the choice to abstain. The choice to abstain may in fact be a strategic behavior of legislators who are cross-pressured between competing demands from a conflictual constituency (Cohen and Noll [1991]), different party wings (Mühlböck [2017]), or constituency on the one hand, and the party leadership on the other hand (Longley [2003]). In these circumstances, abstaining may represent the least costly option, even though it may be interpreted by constituents as evidence of poor representation, and by the leadership as an indication of poor party discipline. We consider the situation in which a legislator is likely to receive a strong pressure by personal connections to support a bill in a roll call vote, while he or she is pushed from the majority of party colleagues to vote against it. This is the case when the majority of a legislator's party colleagues vote against the bill sponsored or cosponsored by an alumni connection. Our results shows that, if the bill under vote is not focal in a legislator's agenda and if the vote is not close, the legislator is more likely to abstain in these situations of conflict than without conflict. ${ }^{2}$

\footnotetext{
${ }^{2}$ A long standing theoretical literature beginning with the seminal works by Downs [1957], and Riker
} 
The effect of social connections is found to be heterogenous across several dimensions. Perhaps unsurprisingly, we find that the impact of social ties on the choice to abstain is lower when the demand for party unity is strongest, that is when there the bill in question is salient to the party. On the contrary, we find no evidence that the influcence of social connections over a legislator's decision to abstain significantly varies when it increases the closeness of the vote. Demographics are another factor that modifies the extent to which social connections impact the choice to abstain. Specifically, we find that ethnic minorities seem to be more supportive of their social connections than other groups, and they are more likely than others to abstain with their political ties. The same is not true when looking at gender, meaning that social connections have similar effects for male and female legislators. The role played by social connections also varies with party affiliation because Democrats show a higher propensity to follow the behavior of connected peers with respect to Republicans. Interestingly, we find that the institutional position held by a Congress member does not interfere with the role played by social connections: the effect of alumni peers is not statistically different for the chair of a committe and the committee members. Also, whereas geography plays a central role in explaining individual turnout (see among others Poole and Rosenthal [1997], Rothenberg and Sanders [1999, 2002], Brown and Goodliffe[2017]), we find that legislators are equally affected by their social connections regardless of how far they must travel to reach Washington D.C..

Our paper adds to a large literature studying the determinats of legislators' abstention in different contexts. ${ }^{3}$ We contribute to this literature by uncovering a novel factor in shaping abstention behavior and revealing a possible mechanism behind this effect.

Building on theoretical work from Fiorina [1974], a small literature focuses specifically on the extent to which the probability of abstention in voting is predicted by the presence of a conflictual situation. ${ }^{4}$ Cohen and Noll [1991] study the roll call votes held on eight bills concerning the funding of the Clinch River Breeder Reactor program during three Congresses (the 94th through the 97th). They find that a legislator is more likely to abstain when he or she faces a conflictual constituency: e.g., constituent groups with opposing views on the same issue. Longley [2003] examines legislators' participation in a single vote held in the Canadian House of Representatives to implement the Canada-U.S. Free Trade Agreement in August 1988. He finds that the probability of abstention increases

and Ordeshook [1968] predicts that abstention is more likely to occur when the policy stakes of the legislator are low and when his/her potential policy influence is minimal.

${ }^{3}$ Specifically, the US House of Representatives (Cohen and Noll [1991]; Poole and Rosenthal [1997]; Rothenberg and Sanders [1999, 2000, 2002]), the US Senate (Forgette and Sala [1999]; Jones [2003]), the US state legislatures (Brown and Goodliffe [2017]), the Canadian House of Commons (Longley [2003]), the European Parliament (Carrubba et al. [2006], Mühlböck and Yordanova [2017]; Noury [2004]), and the Swedish Parliament (Willumsen and Öhberg [2013]).

${ }^{4}$ Theories of abstention in environments with common values and asymmetric information are presented by Dekel and Piccione [2000], Battaglini [2005] and Battaglini, Morton and Palfrey [2007]. These theories focus on the study of how abstention affects information aggregation in elections. 
when the interest of the party conflicts with the individual ideology of the legislator, or with the interest of his or her consituency. More recently, Mühlböck and Yordanova [2017] contribute to this strand of research by considering a larger set of roll call votes. Specifically, they investigate abstention during the 6th legislature of the European Parliament, and find that legislators are more prone to abstain on a roll call vote when torn between different requests from their national party, their transnational party group, and their country's minister. With respect to this literature, we consider a measure of conflict beyond those currently explored and adopt an improved empirical design that helps with identification issues.

The rest of the paper is organized as follows. Section 2 describes the data and defines the variables used in our empirical investigation. While Section 3 is devoted to a first exploration of the data, Section 4 presents the empirical model and the estimation results. Sections 5 and 6 present some additional results and robustness checks. Finally, Section 7 concludes.

\section{Data and Definition of Variables}

We combine data from several sources.

Abstention in roll call votes. Roll call votes are retrieved from the dataset "Members Votes" of the "Voteview: Congressional Roll-Call Votes Database". 5 We consider all votes on bills which took place in the House of Representatives from the 109th Congress (2005-2007) to the 113th Congress (2013-2015). ${ }^{6}$ For each member of Congress, the data indicate whether he or she abstained or cast a vote (either 'yeah' or 'nay') on each roll call. Actual abstention behavior, however, is not so easy to identify. Because the list of representatives changes over a legislature, a problem with using this data to study abstention behavior is that a Congress member is recorded as abstaining on a given roll call vote also when that vote was held while he or she was not serving as a representative. For this reason, we retrieve the official list of representatives on each day of a legislature from the official GitHub page of the government of the United States (https://github.com/unitedstates/congress-legislators), which records the name of all Congress members who served at the House in a given legislature, and the time period in which they were in office. By using this data, we are able to correctly identify the list of actual abstainers in each roll call vote in the considered time period.

Our dependent variable, Abstain $_{i j}$, is a dummy variable equal to one if Congress member $i$ abstained on roll call vote $j$, and equal to zero if Congress member $i$

\footnotetext{
${ }^{5}$ Lewis, Jeffrey B., Keith Poole, Howard Rosenthal, Adam Boche, Aaron Rudkin, and Luke Sonnet (2019). Voteview: Congressional Roll-Call Votes Database. https://voteview.com/

${ }^{6}$ We do not consider roll call votes held on Congressional resolutions because the data sources on these votes are much more limited with respect to those available on bills. Roll call votes held on bills represent $81 \%$ of the roll call votes in our sample
} 
voted either yeah or nay on roll call vote $j .{ }^{7}$

Drivers of abstention behavior. Several factors are indicated in the existing literature as drivers of legislative turnover. A large literature documents that absenteeism is low on partisan-salient votes, that is when most of the party leaders vote in the same way, the so-called key votes (Forgette and Sala [1999]; Rothenberg and Sanders [1999, 2000, 2002]), and when the margin of the vote is small (Poole and Rosenthal [1997]), because these are circumstances when Congress members have the chance to maximize their policy influence. ${ }^{8}$

We identify the key votes using a dummy variable, keyvotes $i_{i j}$, which equals one if all of the leaders of Congress member $i$ 's party vote in the same way on roll call vote $j$, and equals zero otherwise. The construction of this variable is challenging because party leaders may change over the course of a single legislature. To make sure that a key vote is defined by looking at the vote choice of the party leaders who were in charge during the day in which the vote was held, we retrived i) the day in which the vote was held and ii) the list of Congress members who were leaders on that specific day. ${ }^{9}$ The first component is taken from the dataset "Congressional Votes" of the "Voteview: Congressional Roll-Call Votes Database." The second component is hand-collected. Specifically, the names of party leaders and the time period in which they served in this role were collected from the official website of the "History, Art \& Archives of the U.S. House of Representatives" (https://history.house.gov/People/). ${ }^{10}$

In our data, key votes represent $74.4 \%$ of votes cast by Democrats, and $71.7 \%$ of votes cast by Republicans, respectively. The second variable predicted to be associated with low rates of abstentionism is the closeness of a given roll call: the closer a vote is, the greater the chance an additional vote could determine the outcome. Closeness of vote has been measured in different way by the literature

\footnotetext{
${ }^{7}$ Note that paired abstention, that is an arrangement between two Congress members of opposing parties that allows them to miss occasional votes in the House and nullify the effect of absences on the outcome of recorded votes, did not occurr in the Congresses under analysis. According to the report on "Pairing in Congressional Voting" prepared by the Congressional Research Service (https://fas.org/sgp/crs/misc/98-970.pdf), the last paired abstention occured in the House of Representatives was registered during the 108th Congress. According to literature (see Cohen and Noll [1991] and Forgette and Sala [1999] among others), paired abstention should be discarded from data.

${ }^{8}$ A different behavior is observed among U.S. state legislators, who are found to be favoring reelection concerns over policy influence: i.e. they prefer to skip high-profile votes and take an inoffensive position so as not to alienate the support of their constituency (Brown and Goodliffe [2017]).

${ }^{9}$ We use the official definition of party leaders provided by the Office of Clerk of the U.S. House of Representatives (http://clerk.house.gov/member_info/leadership.aspx). According to this definition, Democrat leaders are: the Speaker of the House (if Democrats are the majority party), the Majority/Minority leader and the Majority/Minority Whip (depending on whether Democrats are the majority or the minority party), the House Assistant Democratic Leader, the Democratic Caucus Chairman, and the Democratic Caucus Vice Chair; while Republican leaders are: the Speaker of the House (if Republicans are the majority party), the Majority/Minority leader and the Majority/Minority Whip (depending on whether Republicans are the majority or the minority party), the Republican Conference Chair, the Republican Conference Vice Chair, and the Republican Policy Committee Chair.

${ }^{10}$ Observe that this information is not contained in existing data sets, such as those provided by the Centre for Legislative Effectiveness (https://thelawmakers.org/). Existing data record whether someone has been a party leader during a legislature, but they do not provide information about the exact time period in which he or she was a party leader, thus making it impossible to observe the vote choice of the party leaders during a given roll call vote.
} 
on abstention (see among others Cohen and Noll [1991], Poole and Rosenthal [1997], Forgette and Sala [1999], Rothenberg and Sanders [2000], Noury [2004]). We follow the recent approach proposed by Noury [2004] and measure it as 1 -

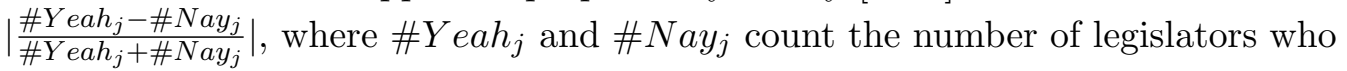
respectively voted 'yeah' and 'nay' on roll call vote $j$. This is a continuos variable that ranges from zero to one. It is equal to zero when there is a unanimous vote (all voting legislators vote either in favor of or against the issue under roll call), and it approaches one when the vote is close and there is almost an even number of voters in favor of and against the issue under roll call. We expect abstention to decrease as vote closeness increases.

In addition to the above mentioned characteristics of the roll call, the literature also indicates a few characterictics of the Congress member typically associated with low levels of abstentionism. The first is individual ideology as measured by the absolute value of the first dimension of the DW ideology score (McCarty et al. [1997]). This variable is used extensively in studying legislative voting. It is readily available in the dataset "Members Ideology" of the "Voteview: Congressional Roll-Call Votes Database." As this variable approaches zero, the legislator is considered a moderate, and when it is close to one, the legislator is considered an extremist. Legislators holding extremist positions are usually less supportive of their party because their ideological preferences are often indifferent between the policy change proposed by a fellow party member in a bill under vote and the status quo (Poole and Rosenthal [1997]). As a consequence, they are more likely to abstain than moderates (Hibbing [1982]). In the literature on abstention behavior (Noury [2004], Poole and Rosenthal [1997], Rothenberg and Sanders $[1999,2000,2002])$, this information is also used to construct another variable, called Ideology distance differential. For each vote $j$, it measures the ideological position of the Yeah and Nay alternatives on roll call vote $j$ compared to the ideological position of the Congress member $i$ (Rothenberg and Sanders, 2000). It is measured using $X_{i}\left(Y_{j}-N_{j}\right)$ where $X_{i}$ is equal to the first dimension of the DW nominate score of Congress member $i$, while $Y_{j}$ and $N_{j}$ are equal to the first dimension of the average value of the DW nominate scores of the Congress members who voted Yeah and Nay, respectively, on roll call vote $j$ (Poole [2005]). ${ }^{11}$ The value $\left(Y_{j}-N_{j}\right)$ is referred to as the midpoint estimate of bill $j$ (Poole and Rosenthal [1997]), and it is provided in the dataset "Congressional Votes" of the "Voteview: Congressional Roll-Call Votes Database." There is vast evidence on the US House of Representatives that a Congress member is likely to cast a vote,

\footnotetext{
${ }^{11}$ To be precise, the Ideology distance differential is equal to $-\sum_{k=1}^{s}\left(X_{i k}-Y_{j k}\right)^{2}-$ $\sum_{k=1}^{s}\left(X_{i k}-N_{j k}\right)^{2}$, where $k$ is the dimension of the DW ideology score. Since we only consider the first dimension of this score (i.e. $k=1)$, the formula reduces to $-\left(X_{i}-Y_{j}\right)^{2}-\left(X_{i}-N_{j}\right)^{2}$, which can be rewritten as $-\left(X_{i}-Y_{j}\right)^{2}-\left(X_{i}-N_{j}\right)^{2}=-2 X_{i}\left(N_{j}-Y_{j}\right)+\left(N_{j}-Y_{j}\right)\left(N_{j}+Y_{j}\right)$. This shows that Ideology distance differential is equal to the sum of a specific value assigned to each legislator $i$ who voted on roll call $j$, that is $-2 X_{i}\left(N_{j}-Y_{j}\right)=2 X_{i}\left(Y_{j}-N_{j}\right)$, and a value common to all legislators who voted on roll call $j$, i.e. $\left(N_{j}-Y_{j}\right)\left(N_{j}+Y_{j}\right)$. Since the latter term is a simple rescaling factor, one can discard it and proxy the variable Ideology distance differential with the value $X_{i}\left(Y_{j}-N_{j}\right)$.
} 
and therefore absenteeism is low, when his or her ideological position is close to one of the alternative position, and far from the other alternative position: i.e. the value of the Ideology distance differential is high (Rothenberg and Sanders $[1999,2000,2002])$.

Turning to the variables traditionally associated with the occurence of abstention behavior in roll calls, it is well documented that absenteeism is higher on Monday and Friday because legislators spend extended weekends in their districts (Noury [2004] and Rothenberg and Sanders [1999, 2000, 2002]), and when a legislator misses other votes on a particular day because the legislator may be away from Capitol Hill (Brown and Goodliffe [2017]). The physical distance of a Congress member's district from Washington D.C., and the competing obligations of a legislator are also likely to prevent participation in some votes. In fact, a legislator may be forced to take prolonged leave from Congress when long travel is required to meet his or her own constituency (see among others Poole and Rosenthal [1997], Rothenberg and Sanders [1999, 2002], Brown and Goodliffe[2017]). To account for these factors, we create the following variables. First, we construct a dummy variable corresponding to the so-called Thursday-Tuesday club behavior. This takes the value one if vote $j$ occured on a Tuesday, Wednesday or Thursday, and zero otherwise. Second, we create the variable Abstained more than once that day, which takes the value one if vote $j$ occured on day $t$ in which Congress member $i$ abstained from more than one vote, and zero otherwise. Next, following the approach by Hart and Munger [1989] and Rothenmberg and Sanders [2002], we create a variable that records the distance in kilometers between a legislator's district centroid and Capitol Hill in Washington, D.C. The maps used to create this variable are taken from the "Digital Boundary Definitions of United States Congressional Districts" project (http://cdmaps.polisci.ucla.edu). Finally, using the "House Committee Assignments Data" we record whether a legislator has a prominent institutional role by creating a dummy variable, chairmanship, which tracks those who are a chairman of a committe in a given legislature. ${ }^{12}$

Last but not least, an important determinant of vote participation is the salience of the subject under vote. In fact, the policy area discussed in the roll call vote might be more or less relevant in a given legislature, and political groups may not react in the same way to different issues (Noury [2004]). We identify the policy content of a roll call using data retrieved from the Policy Agendas Project (PAP) topic system (www.comparativeagendas.net/us). PAP data provides information about the policy content of all roll calls votes held on bills. Specifically, PAP associates the policy content of each roll call vote to one out of 250 topic subject categories, which are uniquely associated to one out of 20 major policy areas: i.e., Macroeconomics, Civil Rights, Health, Agriculture, Labor, Education, Environment, Energy, Immigration, Transportation, Law and Crime, Social Welfare, Housing, Domestic Commerce, Defense, Technology, Foreign Trade,

\footnotetext{
${ }^{12}$ House Committee Assignments Data are obtained from http://web.mit.edu/17.251/www/data page.html\#2.
} 
International Affairs, Government Operations, Public Lands, and Culture. A precise definition of the policy content related to each PAP category is available at https://www.comparativeagendas.net/pages/master-codebook, and reported in Appendix, Table A4. We create a dummy variable for each major policy area coded by the PAP topic system. The dummy variable associated with a major policy area takes the value one if the policy content of roll call vote $j$ on day $t$ refers to that policy area, and zero otherwise.

Vote participation is not only shaped by the salience of the policy area of the roll call in the legislature, but also by the relevance of the topic subject for the legislator's policy agenda. Legislators may indeed be indifferent to specific topic subjects, and not interested in investing time to form a position or to participate in the vote on those topic subjects (Forgette and Sala [1999], Scully [1997]). On the contrary, when the topic subject of a proposal is salient to a Congress member, he or she is less likely to abstain. For each Congress member, we identify the specific policy interest on a given roll call in the following way. We retrieve the data provided by the Congressional Bills Project (http://congressionalbills.org), which categorizes the bills sponsored and cosponsored by each Congress member using the same policy topic coding system provided by the PAP data. For each Congress member $i$, we count the bills where the Congress member $i$ was an original sponsor or an original cosponsor in each policy topic subject (250 categories) and identify his or her most recurrent topic subject category. ${ }^{13}$ We assume that Congress member $i$ has a specific interest in roll call vote $j$ if the bill under vote is in his or her most recurrent topic subject category. Figure 1 shows the number of Congress members with a particular policy interest on a specific topic subject, as inferred by their cosponsorship activity. In the figure, the x-axis reports the PAP Code relative to the topic subject of the bills sponsored or cosponsored by Congress members. Topic subjects are grouped according to their policy area, which are reported on top of the plot (see Table A4 for precise definitions of the policy content of each PAP code). We find that Congress members have a wide variety of topic subjects relevant to their political agenda. The most frequently discussed issues in bills in the 109th-113th Congresses are: macroeconomic policies related to taxation (PAP code 107), defense policies dealing with military personnel issues (PAP code 1608), and federal appropriation policies to implement commemorative acts (PAP code 2006). Other relevant areas include: health care policies for the regulation of insurances (PAP code 302), foreign trade policies related to tariffs and imports (PAP code 1807), and government property management, construction, and regulation (PAP code 2008).

We also consider the role of demographics and party affiliation in shaping vote

\footnotetext{
${ }^{13}$ Specifically, we order the interest of a legislator for different topic subjects by ranking first the topic subject category on which he or she has sponsored or cosponsored the highest number of bills. The topic subject category corresponding to the highest ranking is considered the most relevant to the legislator's agenda. When multiple topic subject categories are ranked first, because the legislator sponsored or cosponsored same number of bills for these categories, we consider all of these categories to be relevant to the legislator's agenda.
} 
turnout, which, to the best of our knowledge, has not received much attention in the existing literature (see Volden and Wiseman [2009] for some considerations on this issue). We collect information about each legislators' gender, race, party affiliation, and seniority from the Center for Effective Lawmaking (https://thelawmakers.org/data-download).

Networks in Congress. A growing literature in political science and economics has provided causal evidence that the personal social networks of legislators have a major impact on their legislative activities (see Battaglini and Patacchini [2019] for a review). Following this nascent literature, we assume that a tie between two Congress members exists if they graduated from the same educational institution within four years of each other. ${ }^{14}$ This social network is obtained by retriving information on the high schools and higher education institutions attended for both undergraduate and graduate degrees from the Biographical Directory of the United States Congress (http://bioguide.Congress.gov/biosearch/ biosearch.asp). A representation of these alumni networks in the considered Congresses is provided in Figure 2, where each dot represents a Congress member, and its color indicates the member's party. The plots clearly show that alumni connections create a vast and dense network of relations between Congress members and bind toghether many Democrats and Republicans. The extent to which alumni networks span across parties is shown in Figure 3. Here, we calculated the percentage of alumni affiliated with the same party and the percentage of alumni affiliated with a different party. The black bars indicate the average percentage of alumni affiliated with the same party, and the white bars indicate the average percentage of alumni affiliated with a different party in each Congress. The figure shows that, on average, $60 \%$ of alumni connections occur between Congress members from the same party, and the remaining 40\% link legislators from different parties. Figure 4 investigates the extent to which these alumni networks represent professional networks. For each Congress member, we calculate the percentage of alumni who are cosponsors and the percentage of alumni who are not cosponsors. Cosponsorship networks have been used to measure the collaborative network in Congress (Kirkland and Gross [2014]) because they connect legislators working on the same topic. This data is retrieved from the updated version of the cosponsorship networks used in Fowler [2006a,b] (http://jhfowler.ucsd.edu/cosponsorship.htm). In line with a literature documenting that personal relationships matter in the cosponsorship decision of a legislator (Fowler [2006a], Battaglini and Patacchini [2018]), Figure 4 shows that between 20 and $30 \%$ of Congress members have a cosponsorship collaboration with their alumni connections in our sample period. However, the overlap between the alumni networks and the cosponsorship networks is not large, suggesting that alumni networks in Congress collect members with a heteroge-

\footnotetext{
${ }^{14} \mathrm{~A}$ four-year time window allows for some overlap and post-graduation interactions, because most universities make signicant efforts to connect alumni graduating in nearby cohorts. The relevance of alumni connections in shaping politicians' voting behavior, campaign contributions, and legislative effectiveness has been demonstrated by Cohen and Malloy [2014], Battaglini and Patacchini [2018], and Battaglini et al. [2020], respectively.
} 
nous policy agenda. Figure 5 reports the distribution of Congress members by alumni connection in each Congress. About $50 \%$ of Congress members in each considered legislature have at least one alumni connection in Congress. Roughly $45 \%$ of the connected legislators have two or more social connections. Using the alumni network, we construct the dummy variable AlumniPeer $s_{i j t}$, which takes the value one if the majority of legislator's $i$ alumni peers abstained on bill $j$ on day $t$, and zero otherwise.

\section{Motivating Evidence}

We start by discussing the frequency of abstention in Congress and presenting evidence that abstention has the potential to influence roll call outcomes in a nontrivial number of votes. Table 1 shows the abstention rate and its importance for the entire universe of votes (column 1), close votes (column 2) and key votes (column 3). On average, Congress members abstain from $4.2 \%$ of votes (column 1 ). Consistent with expectations, this value drops when the vote is close (column 2 ), or it is a key vote (column 3). In fact, these are the instances when the legislator's vote is most valuable to the party and he or she is likely to be highly pressured to turn out and support co-partisan peers. The second row of the table records the fraction of roll calls where the number of abstainers exceeded the margin of the vote. These are cases where it was possible that abstainers could have changed the outcome of the vote. The table shows that about $4 \%$ of all considered roll call votes were decided by a margin that was smaller than the number of abstainers. In line with expectations, this percentage is twice as high for close votes. In contrast, abstention is less relevant for the outcome of key votes.

We report the abstention rate of Congress members from different groups in Table 2. We begin by examining whether abstention behavior differs for legislators with different demographic characteristics and party affiliation. We find that the abstention rate of women and ethnic minorities is, on average, at least one percentage point higher than other legislators. We also find that the abstention rate of legislators with more extreme ideologies is higher than that of moderate legislators. This is not surprising because legislators with moderate ideologies usually care about a higher number of bills under vote, while extremists are usually indifferent between the status quo and the change promoted in many bills (Poole and Rosenthal [1997]). When turning to party affiliation, we find no striking differences among Republicans and Democrats. Consistent with the idea that legislators might be forced to miss votes in order to meet with their constituency, we find that legislators who require longer travel in order to reach their electoral district tend to abstain more than their colleagues coming from electoral districts closer to Washington D.C. ${ }^{15}$ We also observe that Congress members

\footnotetext{
${ }^{15}$ In order to define whether a district is near Washington D.C., we record the distance of each district's centroid from this city. Then, we compute the median distance of the electoral districts from Washington
} 
abstain twice as much on Mondays and Fridays than during midweek days, and that committee chairs tend to abstain slightly more often than other members, even if the difference between the two groups is not statistically significant.

We now examine Congress members exposed to peers who abstain. Roughly $40 \%$ of legislators in Congress have at least one peer who abstains in any roll call in the period considered. ${ }^{16}$ Figure 6 shows the distribution of Congress members with at least one peer who abstained by percentage of peers who abstain in the different Congresses. The pictures shows that while the percentage of connected peers who abstain on a roll call vote is small (10-20\%) for most Congress members. However, about $10 \%$ of members have the majority of their peers abstain. Importantly, the picture shows substantial variation among Congress members in exposure to peers who abstain. In Figure 7, we plot the distribution of Congress members who abstain by the percentage of peers who abstain in the different Congresses. While abstention decisions are driven by a variety of factors, it is remarkable to see that, especially in the more recent Congresses, abstention rates are higher, on average, when a higher share of peers abstain. In the 112th and 113 th Congress, we observe that, on average, more than $50 \%$ of legislators abstain when $80 \%$ or more of their peers abstain.

\section{Empirical Strategy and Baseline Results}

To explore whether alumni connections have an impact a legislator's propensity to abstain, we analyze each Congress member's voting behavior for every roll call vote as well as that of the legislator's alumni peers during the same vote in five different legislatures. Specifically, we are interested in the difference between a legislator's abstention behavior for a given roll call vote if the majority of his or her alumni ties abstain and that legislator's abstention behavior if the majority of the alumni ties do not. We focus our analysis on the effects of the majority of peers because, while there is a positive effect of the share of peers who abstain on own abstention behavior, this effect is non-linear and acquires importance only if the share of peers who abstain is greater than $50 \% .{ }^{17}$ We document this non-linearity in the last column of Table 3 . We estimate the following regression model:

D.C., which is $1,966.374 \mathrm{kms}$. If a district is located within 1,966.374 kms of Washington D.C., then it is recorded as being near this city, and distant otherwise.

${ }^{16}$ Specifically, the percentage of legislators who have at least one peer who abstained in any roll call vote is: $35.3 \%$ in the 109th Congress, $35.8 \%$ in the 110 th Congress, $41.1 \%$ in the 111 th Congress, $43.6 \%$ in the 112 th Congress, and $39.9 \%$ in the 113th Congress.

${ }^{17} \mathrm{We}$ do not use data on the exact order of the votes in the roll-call, since real time data on the voting outcome is not even available to the legislators during the roll-call. (On the south wall of the chamber there is an electronic display board, but it displays only a running tally of the vote, not the individual choices.) In our analysis, we assume that decisions concerning abstentions are taken before the beginning of the vote. This is illustrated by the citation from Caro [2013] at the beginning of the paper, making clear how Lyndon B. Johnson would make arrangements with Harry Byrd before votes were called. 


$$
\text { Abstain }_{i j t c}=\beta_{0}+\beta_{1} \text { AlumniPeers } s_{i j t c}+\beta_{2} W_{i j t c}+\beta_{3} X_{j t c}+v_{i}+\zeta_{c}+\epsilon_{i j t c}
$$

where the decision to abstain of legislator $i$ during roll call vote $j$ on day $t$ during Congress $c$, as measured by the variable Abstain $_{i j t c}$, is a function of the choice of $i$ 's majority alumni peers to abstain, represented by the variable AlumniPeer $s_{i j t c}$, of legislator characteristics (in the set $W_{i j t c}$ ), and of roll call vote characteristics (in the set $X_{j t c}$ ). The characteristics of a roll call vote include dummies indicating the policy area discussed in the bill under vote, whether or not the roll call vote is held during midweek days (Tuesday, Wednesday or Thurday), whether it is a key vote, and the closeness of vote. The model includes individual legislator and Congress fixed effects $\left(v_{i}\right.$ and $\zeta_{c}$, respectively) and a random error term $\epsilon_{i j c}$. The inclusion of individual fixed effects controls for the effects of timeinvariant characteristics of legislators possibly correlated with abstention choices, such as the distance from their respective districts, and the competing obligations that they may have because of their role in the party (e.g. party leaders) or in the House (e.g. committee chairs). Observe that it also captures whether the Congress member has alumni connections in Congress or not. ${ }^{18}$ The remaining time-varying characteristics of the legislator, which are included in the set $W_{i j t c}$, are the difference between the ideological position of the legislator and the "Yeah Position" and "Nay Position", registered by the variable Ideology distance differential, and whether the legislator already abstained at least once on the same day in which the vote was held, recorded by the variable Abstained more than once that day.

The results are contained in Table 3. In order to ease the comparison of estimated coefficients, we report standardized estimation results. ${ }^{19}$

We start the analysis in column 1 by including in model (1) only the variables that the existing literature indicates as important determinants of abstention in Congress (see Section 3). Consistent with these studies, we find that all of the drivers of abstention detected by previous research matter in shaping the individual abstention behavior. When legislators' indifference for the outcome of the bill under vote is high - as measured by the Ideology distance differential - they are more likely to abstain. The same pattern holds when politicians have competing obligations. We also find evidence of the Thursday-Tuesday club behavior, which suggests that the commitment to meet with constituents often conflicts with legislative activities. In contrasts, legislators are more prone to turnout during key votes and when the margin of a vote decreases, that is when the demand for party unity by the leadership is the strongest. We also find an expected positive and significant sign on the estimated effects of the variable Abstained more than once that day, which controls for the possibility that abstention during a given roll

\footnotetext{
${ }^{18}$ We will investigate the robustness of our results to the exclusion of Congress members without alumni connections in Congress in Section 7.

${ }^{19}$ We standardize the estimated effects using the formula $\frac{s d(x)}{s d(y)} \beta_{x}$, where $\beta_{x}$ is the estimated effect of variable $x$, while $s d(x)$ and $s d(y)$ indicate the standard deviation of the variable $x$ and dependent variable $y$, respectively.
} 
call vote is simply driven by the fact that the legislator is missing from Capitol Hill that day. In column 2, we test whether there is an additional effect coming from the alumni connections. The estimated effect is statistically significant and sizable in magnitude given the number of control variables and fixed effects included in the model. We find that having the majority of alumni connections who abstain is associated with a 2 percentage point increase in the probability that a legislator abstains. The effect is about $5 \%$ of a standard deviation. To better understand the importance of this effect, observe that it has magnitude equal to roughly $70 \%$ of the impact of Key vote, a well-know important driver of vote participation, and is of the opposite sign. That is, the magnitude of the effect exerted by the alumni network is such that it could almost counterveil the incentive to turn out stemming from party leadership. In columns 3 and 4, we test whether the effects are due to two crucial characteristics of the legislators' peers: their party and their policy agenda. In column 3, we split the variable

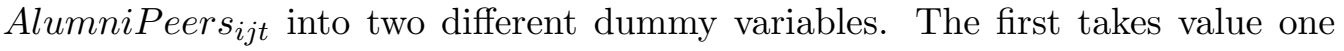
if the majority of legislator $i$ 's alumni connections that are also affiliated with $i$ 's party abstained on vote $j$, and zero otherwise. The second takes one if the majority of legislator $i$ 's alumni connections that are not affiliated with $i$ 's party abstained on vote $j$, and zero otherwise. Perhaps unsurprisingly, the results show that the behavior of friends of the same party is more important than the behavior of friends of different parties in shaping a legislator's own abstention choice. The difference between the two effects is statistically significant (Wald $\chi^{2}$ test equal to 7.1, p-value equal to 0.0078). However, the estimated effects of both types of friends are statistically significant, indicating that alumni connections are relevant for the choice to abstain regardless of their party affiliation. In column 4, we instead split the variable AlumniPeers $s_{i j t}$ into two different dummy variables using legislative cosponsorships. The first takes the value one if the majority of legislator $i$ 's alumni connections with whom $i$ cosponsored a bill abstained on vote $j$, and zero otherwise. The second takes the value one if the majority of legislator $i$ 's alumni connections who did not cosponsor a bill with $i$ abstained on vote $j$, and zero otherwise. Interestingly, we find that the abstention behavior of peers is relevant irrespective of whether or not they are cosponsors or no. The estimated effects for the two groups are positive, but not statistically different from each other (Wald $\chi^{2}$ test equal to $0.36, \mathrm{p}$-value equal to 0.55 ). This evidence suggests that our result is not primarily driven by shared interests in law-making.

In column 5, we consider the possibility that our results are due to a specific inclination of the legislator and his or her social connections towards the specific issues contained in the bill under vote (for example because of low interest in the bill's overall content). Because multiple roll call votes are held on the same bill, we augment regression model (1) with bill fixed effects. This allow us to observe the voting behavior of legislators during roll call votes held on the same bill, holding costant the characteristics of the bill. As a result, if the choice to abstain is motivated by a specific inclination of the legislator and of his or 
her social connections toward the characteristics of the bill under vote, network effects will no longer be a significant predictor of abstention. On the other hand, if network effects motivate the choice to abstain then we would expect them to be a significant driver of abstention even when controlling for the characteristics of the bill under vote. Specifically, model (1) now becomes:

$$
\text { Abstain }_{i j t b}=\beta_{0}+\beta_{1} \text { AlumniPeers }_{i j t b}+\beta_{2} W_{i j t b}+\beta_{3} X_{j t b}+v_{i}+\zeta_{b}+\epsilon_{i j t b}
$$

where the decision to abstain of legislator $i$ during roll call vote $j$ on day $t$ held on bill $b$, as measured by the variable $A_{b s t a i n}$ ijtb $_{\text {, }}$, is a function of the choice of $i$ 's majority alumni peers to abstain AlumniPeer $s_{i j t b}$, the set of control variables included in regression model 1, the individual fixed effects $\left(v_{i}\right)$ and the bill fixed effects $\left(\zeta_{b}\right)$. The estimation results (Table 3, column 5) show that the evidence remains qualitatively unchanged. The effect of social connections remains positive and statistically significant, although perhaps unsurprisingly it is greatly reduced in magnitude. These results suggests that the characteristics of the bill under vote might explain the behavior of connected legislators in some cases, but that the estimated network effects are not entirely driven by the shared interest of connected legislators for specific bills.

Finally, we investigate the extent to which the network effect in abstention varies with exposure. In our analysis, the influence of peers is modeled in a specific way, which is looking at the behavior of the majority. This choice is motivated by the fact that the influence of peers is non-linear in the share of peers who abstain. In column 6 we investigate how abstention behavior changes with different shares of peers who abstain. We consider quantiles of this share distribution and replace the variable Abstain $_{i j t b}$ in model (2) with four dummy variables corresponding to quartiles of the distribution of abstained peer legislators. The first dummy takes the value one if the percentage of legislator $i$ 's alumni connections who abstain is less than or equal to $25 \%$, and zero otherwise. The second takes value one if the percentage legislator $i$ 's alumni connections who abstain is more than $25 \%$ and less than or equal to $50 \%$, and zero otherwise. The third takes value one if the percentage of legislator $i$ 's alumni connections who abstain is more than $50 \%$ and less than or equal to $75 \%$, and zero otherwise. The fourth takes value one if more than $75 \%$ of legislator $i$ 's alumni connections abstain, and zero otherwise. The estimates show that while the abstention behavior of peers is unrelated to a legislator's own behavior when the share of peers who abstain is lower than $50 \%$, it becomes important when higher shares of peers abstain. The effects are increasing with the shares of peers and statistically different (Wald $\chi^{2}$ test equal to 11 , p-value equal to 0.0009$)$, but very similar in magnitude ( $2 \%$ of a standard deviation vs $2.4 \%$ of a standard deviation). This is why in our analysis we pooled together all shares greater than $50 \%$. 


\section{Abstention and Conflict}

We next consider the situations in which a legislator likely faces conflicting pressures from social connections on one side and party colleagues on the other side. Specifically, we analyze a legislator's abstention behavior when the legislator's party opposes a bill sponsored or cosponsored by the legislator's personal connections. Some scholars have expressed concern that legislative cosponsorships are not very informative because they are a form of "cheap talk" (Kessler and Krehbiel [1996]; Wilsonand and Young [1997]). However, as stressed by Fowler [2006a], the number of bills cosponsored by each legislator is only a tiny fraction of the bills they may have chosen to support, and substantial search costs are invested in deciding which bills to cosponsor. Consequently, it is reasonable to expect that legislators care about their cosponsorship activity and thus may lobby their social connections to vote in favor of the bills they cosponsored. This might be even more prevalent when the bill is directly sponsored by them.

As mentioned in the introduction, we expect that the choice to abstain will be more common when the policy stakes of the legislator are low. According to this theory, we predict that a legislator will be less likely to abstain when his or her potential policy influence is maximized, as is the case when a vote is particularly relevant to the legislator's agenda, or when the outcome of the vote is expected to be close.

We construct a dummy variable taking value the one when the majority of $i$ 's party colleagues vote against the bill sponsored or cosponsored by an alumni connection on roll call vote $j$ held on day $t$ during congress $c$, and zero otherwise. We estimate the regression model

(3) Abstain $_{i j t c}=\beta_{0}+\beta_{1}$ DivergingPeers $s_{i j t c}+\beta_{2} W_{i j t c}+\beta_{3} X_{j t c}+v_{i}+\zeta_{c}+\epsilon_{i j t c}$

where DivergingPeers $s_{i j c}$ represents the conflict faced by the legislator, and the other variables are the same as in model (1).

The estimation results are reported in Table 4. The first column shows the results for all roll call votes. In columns 2 and 3, we distinguish between roll call votes on topics that are either relevant or relevant for a legislator's policy agenda, that is between situations where network mechanisms are likely to be more or less important. We expect that a legislator may find it hard to abstain when the topic is related to his or her agenda, whereas if the topic is not relevant to the politician's interests then the supply of votes that can be influenced by peers is high (Cohen and Malloy, 2014). When the cost of abstention is low, the benefit of avoiding a conflict might offset the cost and thus induce the legislator to abstain. We measure the relevance of the vote to a given politician according to the definition of bill topic salience presented in Section 3. According to the expectations, the results show an effect of conflict on a legislator's propensity to abstain in column 1 that is driven by the roll calls where the vote is not relevant to the legislator's agenda (column 3). In line with the theory, this evidence shows 
that when the policy stakes of the vote are low, the legislator is more likely to be affected by conflict. By abstaining, he or she can mantain both the relationships with the alumni network on one hand, and the party on the other hand.

In columns 4 and 5 , we vary the cost of abstention by considering roll calls with a different vote margin. Again, the results are consistent with the idea that personal connections may create conflictual situations that trigger abstention when the costs of doing so are low. In fact, the results show that when the cost is high (i.e., when the vote is close, column 4), conflict does not exert a statistically significant effect on the decision of a legislator to abstain. The effect becomes statistically significant and increasing in magnitude when the margin of vote increases, or in other words, when the cost of abstention decreases.

\section{Heterogeneity}

In this section we investigate whether the effect of alumni connections is different for legislators or roll call votes with differerent characteristics, and in Congresses with different structures. We estimate the augmented version of model (1):

(4) Abstain $_{i j t c}=\beta_{0}+\beta_{1}$ AlumniPeers $s_{i j t c}+\delta_{1}$ AlumniPeers $s_{i j t c *}$ interaction_variable $+\delta_{2}$ interaction_variable $+\beta_{2} W_{i j t c}+\beta_{3} X_{j t c}+v_{i}+\zeta_{c}+\epsilon_{i j t c}$

where interaction variable captures the following characteristics: the vote is a key vote, the vote is close, the legislator is a woman, belongs to an ethnic minority, is a Democrat, is the chair of a committee, has a marked ideological position, or travels further between their district and Washington D.C.. We expect that party demands are larger and the influence of social connections is smaller for key votes and close votes. We also expect no impact on politicians whose constituency lives far from Washington D.C. because geography should not interfere with network effects. The effects of demographic charateristics, institutional positions, party affiliations, and ideology are a matter of empirical investigation.

The results contained in columns 1 and 2 of Table 5 confirm that the effect exerted by the alumni network is mitigated for key votes and close votes. However, the decrease of the network effect is statistically significant only when considering key votes. Columns 3-5 of Table 5 present the results of the estimation of model 4 when considering the interaction of network effects with the demographics and the party affiliation of the legislator. We find that gender does not significantly interfere with peer effects (column 4), whereas ethnic minorities are more prone to abstain with their connected peers than the majority of their colleagues (column 5). We also find that Democrats are more likely to abstain with their social connections with respect to Republicans (column 5). No significant differences in the effect exerted by the alumni network are observed between committee chairs and other members of the Congress, between politicians with more or less extreme 
ideology and those whose electoral district is closer or farther from Washington D.C.

\section{Robustness checks}

Our analysis on the effect of personal connections on abstention behavior is performed using infomation on all Congress members regardless of whether or not they have alumni connections in Congress. This is because our identification strategy is based on the use of individual fixed effects, or in other words, on the comparison of abstention behavior of the same Congress member when exposed to a different share of peers who abstain. However, there are some slight differences between legislators who have social connections, and those that do not. They are presented in Appendix Table A2. In order to be sure that unobserved factors related to those differences do not bias our results, we replicate the analysis presented previously in Table 3 by considering only the sample of Congress members who have at least one connected peer. The results of this exercise are presented in Appendix Table A3. All of the results remain qualitatively unchanged. The point estimates are only slighly larger in magnitude.

\section{Conclusions}

This paper investigates the role of social connections on abstention behavior in the U.S. House of Representatives. Our analysis is conducted by observing representatives' participation in the universe of roll call votes held on bills from the 109th through 113th Congress. Specifically, we observe how a legislator's decision to abstain is affected by the behavior of his or her network over different roll call votes, holding the network characteristics constant. We show that the social network of a legislator influences his/her abstention choices, even after controlling for all other well-known predictors of abstention.

Specifically, we find evidence that the propensity to abstain increases when the majority of a legislator's alumni connections choose to abstain. The magnitude of this effect is such that it could counterveil the incentive to vote that increases as the margin of a vote narrows. We further show that a possible pathway for this effect is the presence of a conflictual situation where the demands of friends clash with those of the legislator's party. This is the case when a legislator must choose whether to support a bill sponsored or cosponsored by a social connection but not his or her party. In these situations, a legislator is more prone to abstain, thus avoiding taking sides. We show however, that this behavior changes according to the policy stakes faced by the legislator over the vote's outcome. Specifically, we show that a cross-pressured legislator prefers to abstain over turn out only when the bill under vote is not relevant to his or her agenda and the margin of vote is large.

Additional insights on the role played by social connections are obtained when looking at their heterogenous role across several dimensions. In particular, we 
observe that Democrats are more inclined than Republicans to behave in accordance with their alumni peers, and that network mechanisms are less relevant when the vote is a key vote or the vote margin is close.

\section{References}

Battaglini, Marco (2005), "Sequential Voting with Abstention," Games and Economic Behavior, 51 (2): 445-463.

Battaglini, Marco, Rebecca Morton, and Thomas Palfrey (2007), "Efficiency, Equity and Timing in Voting Mechanisms," American Political Science Review, 101(3): 409-424.

Battaglini, Marco, and Eleonora Patacchini (2018), "Influencing connected legislators," Journal of Political Economy 126 (6): 2277-2322.

Battaglini, Marco and Eleonora Patacchini (2019), "Social Networks in Policy Making," Annual Reviews of Economics, 11: 473-494.

Battaglini, Marco, Valerio Leone Sciabolazza, and Eleonora Patacchini (2020), "Effectiveness of connected legislator," American Journal of Political Science, forthcoming.

Brown, Adam R. and Jay Goodliffe (2017), "Why Do Legislators Skip Votes," Political Behavior, 39:442-45.

Caro, Robert (2013), The Years of Lyndon Johnson: The Passage of Power, New York, Knopf.

Carrubba, Clifford, Matthew Gabel, Lacey Murrah, Ryan Clough, Elizabeth Montgomery, and Rebecca Shambaugh, R. (2006), "Off the record: Unrecorded legislative votes, selection bias and roll-call vote analysis," British Journal of Political Science, 36: 691-704

Cohen, Lauren, and Christopher J. Malloy (2014), "Friends in high places," American Economic Journal: Economic Policy, 6 (3): 63-91.

Cohen, Linda R. and Roger G. Noll (1991), "How to Vote, Whether to Vote: Strategies for Voting and Abstaining on Congressional Roll Calls," Political Behavior 13 (2): 97-127.

Cox, Gary W. and Mathew D. McCubbins (1993), Legislative Leviathan: Party Government in the House. California Series on Social Choice and Political Economy, University of California Press. 
Dekel, Eddie. and Michele Piccione (2000), "Sequential Voting Procedures in Symmetric Binary Elections," Journal of Political Economy, 108: 34-55

Downs, Anthony (1957), An economic theory of democracy, Harper and Row.

Fiorina, Morris P. (1974), Representatives, roll calls, and constituencies. Lexington Books.

Forgette, Richard and Brian R. Sala (1999), "Conditional Party Government and Member Turnout on Senate Recorded Votes, 1873-1935," The Journal of Politics, 61 (2): 467-84.

Fowler, J. H. (2006a), "Connecting the Congress: A study of cosponsorship networks," Political Analysis, 14 (4): 456-487

Fowler, J. H. (2006b), "Legislative cosponsorship networks in the U.S. House and Senate," Social Networks, 28 (4): 454-465.

Hart, Douglas B. and Michael C. Munger (1989), "Declining electoral competitiveness in the House of Representativs: The differential impact of improved transportation technology," Public Choice, 61 (3): 217-228.

Hibbing, John R. (1982), "Voluntary Retirement from the U.S. House of Representatives: Who Quits?" American Journal of Political Science, 26: 467-484

Jones, David R. (2003), "Position Taking and Position Avoidance in the US Senate," The Journal of Politics, 65 (3): 851-63.

Kessler, Daniel, and Keih Krehbiel (1996), "Dynamics of cosponsorship", The American Political Science Review 90 (3): 555-66

Kirkland, Justin H. (2011), "The relational determinants of legislative success: Strong and weak ties between legislators," Journal of Politics, 73 (3): 887-898.

Kirkland, Justin H. and Justin H. Gross, "Measurement and theory in legislative networks: The evolving topology of Congressional collaboration," Social Networks, 36: 97-109.

Longley, Neil (2003), "Modeling the legislator as an agent for the party: The effects of strict party discipline on legislator voting behavior," Contemporary Economic Policy, 21 (4): 490-499. 
Mayer, Kenneth R. and David T. Canon (1999), The Dysfunctional Congress?: The Individual Roots of an Institutional Dilemma. Westview Pr.

Mayhew, David R. (1974), Congress: The Electoral Connection. Vol. 26. Yale University Press.

McCarty, Nolan M., Keith T. Poole, and Howard Rosenthal (1997), Income redistribution and therealignment of American politics, AEI press.

Mühlböck, M. (2017), Voting Unity of National Parties in Bicameral EU DecisionMaking. Speaking with One Voice?, London: Palgrave Macmillan.

Mühlböck, Monika and Nikoleta Yordanova (2017), "When Legislators Choose Not to Decide: Abstentions in the European Parliament," European Union Politics, 18 (2): 323-36.

Noury, Abdul G. (2004), "Abstention in Daylight: Strategic Calculus of Voting in the European Parliament," Public Choice, 121 (1-2): 179-211.

Poole, Keith T. and Howard Rosenthal (1997), Congress: A Political-Economic History of Roll Call Voting. Oxford University Press on Demand.

Riker, William H. and Peter C. Ordeshook (1968), "A Theory of the Calculus of Voting," American Political Science Review, 62 (1): 25-42.

Rothenberg, Lawrence S. and Mitchell Sanders (1999), "Rational Abstention and the Congressional Vote Choice," Economics \& Politics, 11 (3): 311-40.

Rothenberg, Lawrence S. and Mitchell S. Sanders (2000), "Legislator Turnout and the Calculus of Voting: The Determinants of Abstention in the US Congress," Public Choice, 103 (3-4): 259-70.

Rothenberg, Lawrence S. and Mitchell S. Sanders (2002), "Modeling Legislator Decision Making: A Historical Perspective," American Politics Research, 30 (3): 235-64.

Scully, Roger M. (1997), "Policy influence and participation in the European Parliament," Legislative Studies Quarterly, 22 (2): 233-252.

Shull, Steven A. and James M. Vanderleeuw (1987), "What do key votes measure?," Legislative Studies Quarterly, 12 (4): 573-582.

Volden, Craig, and Alan E. Wiseman (2014), Legislative Effectiveness in the 
United States Congress: The Lawmakers, Cambridge University Press.

Willumsen, David M. and Patrik Öhberg (2013), "Strategic abstention in parliamentary voting," EPSA 2013 Annual General Conference Paper, available at https://papers.ssrn.com/sol3/papers.cfm?abstract_id=2225149.

Wilson, Rick K. and Cheryl D. Young (1997), "Cosponsorship in the United States Congress," Legislative Studies Quarterly, 22 (1): 24-43 
Table 1

\begin{tabular}{|c|c|c|c|}
\hline & $\begin{array}{c}\text { Total } \\
\text { (1) } \\
\end{array}$ & $\begin{array}{c}\text { Close Votes } \\
\text { (vote closeness } \geq 0.8) \\
(2)\end{array}$ & $\begin{array}{c}\text { Key Votes } \\
(3) \\
\end{array}$ \\
\hline Average percentage of times a Congress member abstained (stand. dev.) & $\begin{array}{l}4.18 \% \\
(4.28)\end{array}$ & $\begin{array}{l}3.22 \% \\
(4.11)\end{array}$ & $\begin{array}{l}3.86 \% \\
(4.16)\end{array}$ \\
\hline Percentage of times the number of abstainers was higher than the margin of vote & $3.97 \%$ & $9.46 \%$ & $2.44 \%$ \\
\hline
\end{tabular}

Table 2

\begin{tabular}{|c|c|c|c|}
\hline \multicolumn{4}{|c|}{ Abstention rates by Congress member characteristics } \\
\hline & $\begin{array}{r}\text { Percentage of Congress m } \\
\text { (stand. dev }\end{array}$ & s who abstained & $\begin{array}{c}t \text { test } \\
\text { [p value] }\end{array}$ \\
\hline Sample & $\begin{array}{c}\text { Reference Category } \\
(\text { Group }=0)\end{array}$ & $\begin{array}{l}\text { Other category } \\
(\text { Group }=1)\end{array}$ & \\
\hline Gender $(1=$ Female $)$ & $\begin{array}{r}4.00 \% \\
(0.04)\end{array}$ & $\begin{array}{r}5.03 \% \\
(0.06)\end{array}$ & $\begin{array}{l}-1.95^{*} \\
{[0.05]}\end{array}$ \\
\hline Race (1 = No White) & $\begin{array}{r}3.93 \% \\
(0.04)\end{array}$ & $\begin{array}{r}5.77 \% \\
(0.04)\end{array}$ & $\begin{array}{c}-4.27 * * * \\
{[0.00]}\end{array}$ \\
\hline Party (1 = Democrat) & $\begin{array}{r}4.00 \% \\
(0.04)\end{array}$ & $\begin{array}{r}4.37 \% \\
(0.04)\end{array}$ & $\begin{array}{l}-1.18 \\
{[0.24]}\end{array}$ \\
\hline Chairmanship $(1=$ Yes $)$ & $\begin{array}{r}4.16 \% \\
(0.04)\end{array}$ & $\begin{array}{r}4.64 \% \\
(0.05)\end{array}$ & $\begin{array}{l}-0.86 \\
{[0.39]}\end{array}$ \\
\hline Electoral district near to Washington D.C. $(1=$ Yes $)$ & $\begin{array}{r}3.76 \% \\
(0.04)\end{array}$ & $\begin{array}{r}4.56 \% \\
(0.05)\end{array}$ & $\begin{array}{c}-2.60^{* *} \\
{[0.01]}\end{array}$ \\
\hline DW Ideology $(0=$ bottom $10 \%, 1=$ top $10 \%)$ & $\begin{array}{r}3.18 \% \\
(0.03)\end{array}$ & $\begin{array}{r}3.86 \% \\
(0.04)\end{array}$ & $\begin{array}{l}-1.28 \\
{[0.20]}\end{array}$ \\
\hline Thursday-Tuesday club (1 = Yes) & $\begin{array}{r}6.72 \% \\
(0.07) \\
\end{array}$ & $\begin{array}{r}3.64 \% \\
(0.04) \\
\end{array}$ & $\begin{array}{c}4.10 * * * \\
{[0.00]}\end{array}$ \\
\hline
\end{tabular}


Table 3

\begin{tabular}{|c|c|c|c|c|c|c|}
\hline & \multicolumn{6}{|c|}{$\begin{array}{l}\text { Dependent variable: Congress member } i \text { abstained on bill } j \\
(1=\text { Yes, } 0=\text { No })\end{array}$} \\
\hline & OLS & OLS & OLS & OLS & OLS & OLS \\
\hline & 1 & 2 & 3 & 4 & 5 & 6 \\
\hline Alumni Peers ( 1 = Majority Abstained) & & $\begin{array}{c}0.0103 * * * \\
(0.0011)\end{array}$ & & & $\begin{array}{c}0.0055^{* * *} \\
(0.0010)\end{array}$ & \\
\hline Alumni Peers - Same Party (1 = Majority Abstained $)$ & & & $\begin{array}{c}0.0090^{* * *} \\
(0.0014)\end{array}$ & & & \\
\hline Alumni Peers - Different Party (1 = Majority Abstained $)$ & & & $\begin{array}{c}0.0041^{* * *} \\
(0.0007)\end{array}$ & & & \\
\hline Alumni Peers who are cosponsors ( 1 = Majority Abstained $)$ & & & & $\begin{array}{c}0.0082 * * * \\
(0.0012)\end{array}$ & & \\
\hline Alumni Peers who are not cosponsors $(1=$ Majority Abstained $)$ & & & & $\begin{array}{c}0.0042 * * * \\
(0.0010)\end{array}$ & & \\
\hline Alumni Peers ( $1=$ Less than $25 \%$ Abstained $)$ & & & & & & $\begin{array}{c}0.0002 \\
(0.0009)\end{array}$ \\
\hline Alumni Peers ( $1=$ Between $25 \%$ and $50 \%$ Abstained $)$ & & & & & & $\begin{array}{c}0.0010 \\
(0.0008)\end{array}$ \\
\hline Alumni Peers ( $1=$ Between $50 \%$ and $75 \%$ Abstained $)$ & & & & & & $\begin{array}{c}0.0041 * * * \\
(0.0009)\end{array}$ \\
\hline Alumni Peers $(1=$ More than $75 \%$ Abstained $)$ & & & & & & $\begin{array}{c}0.0047 * * * \\
(0.0010)\end{array}$ \\
\hline Ideology Distance Differential & $\begin{array}{c}-0.0181 * * * \\
(0.0008)\end{array}$ & $\begin{array}{c}-0.0180 * * * \\
(0.0008)\end{array}$ & $\begin{array}{c}-0.0180 * * * \\
(0.0008)\end{array}$ & $\begin{array}{c}-0.0180 * * * \\
(0.0008)\end{array}$ & $\begin{array}{c}-0.0045^{* * *} \\
(0.0008)\end{array}$ & $\begin{array}{c}-0.0045^{* * *} \\
(0.0008)\end{array}$ \\
\hline Key vote $(1=$ Yes $)$ & $\begin{array}{l}-0.0142 * * * \\
(0.0012)\end{array}$ & $\begin{array}{l}-0.0141^{* * *} \\
(0.0012)\end{array}$ & $\begin{array}{c}-0.0141 * * * \\
(0.0012)\end{array}$ & $\begin{array}{c}-0.0141 * * * \\
(0.0012)\end{array}$ & $\begin{array}{l}-0.0119 * * * \\
(0.0013)\end{array}$ & $\begin{array}{c}-0.0119^{* * *} \\
(0.0013)\end{array}$ \\
\hline Vote closeness & $\begin{array}{l}-0.0344 * * * \\
(0.0012)\end{array}$ & $\begin{array}{c}-0.0341 * * * \\
(0.0012)\end{array}$ & $\begin{array}{c}-0.0341 * * * \\
(0.0012)\end{array}$ & $\begin{array}{c}-0.0341 * * * \\
(0.0012)\end{array}$ & $\begin{array}{c}-0.0040 * * * \\
(0.0008)\end{array}$ & $\begin{array}{c}-0.0040^{* * *} \\
(0.0008)\end{array}$ \\
\hline Abstained more than once that day $(1=$ Yes $)$ & $\begin{array}{c}0.7205^{* * *} \\
(0.0084)\end{array}$ & $\begin{array}{c}0.7204 * * * \\
(0.0084)\end{array}$ & $\begin{array}{c}0.7204 * * * \\
(0.0084)\end{array}$ & $\begin{array}{c}0.7204 * * * \\
(0.0084)\end{array}$ & $\begin{array}{c}0.7277 * * * \\
(0.0082)\end{array}$ & $\begin{array}{c}0.7277 * * * \\
(0.0082)\end{array}$ \\
\hline Thursday-Tuesday club (1 = Yes) & $\begin{array}{c}-0.0258^{* * *} \\
(0.0013)\end{array}$ & $\begin{array}{c}-0.0255^{* * *} \\
(0.0013)\end{array}$ & $\begin{array}{c}-0.0255^{* * *} * \\
(0.0013)\end{array}$ & $\begin{array}{c}-0.0255^{* * *} \\
(0.0013)\end{array}$ & $\begin{array}{c}-0.0079 * * * \\
(0.0018)\end{array}$ & $\begin{array}{c}-0.0078^{* * *} \\
(0.0018)\end{array}$ \\
\hline $\begin{array}{l}\text { Wald } \chi^{2} \text { test } \\
\text { [p-value] }\end{array}$ & & & $\begin{array}{c}7.10^{* *} \\
{[0.0078]}\end{array}$ & $\begin{array}{c}0.36 \\
{[0.5500]}\end{array}$ & & $\begin{array}{l}11.00 * * * \\
{[0.0009]}\end{array}$ \\
\hline Individual fixed effects & Yes & Yes & Yes & Yes & Yes & Yes \\
\hline Congress fixed effects & Yes & Yes & Yes & Yes & No & No \\
\hline Roll call topic fixed effects & Yes & Yes & Yes & Yes & Yes & Yes \\
\hline Bill fixed effect & No & No & No & No & Yes & Yes \\
\hline $\mathrm{r} 2$ & 0.5364 & 0.5365 & 0.5365 & 0.5365 & 0.5492 & 0.5492 \\
\hline Num. Obs. & $3,143,453$ & $3,143,453$ & $3,143,453$ & $3,143,453$ & $3,143,453$ & $3,143,453$ \\
\hline
\end{tabular}

Note: Results for model (1) of the paper are in columns (1) - (4). Results for model (2) are in columns (5) - (6). Standardized OLS estimated coefficients are reported. Standardization of coefficients is obtained using the formula $\frac{s d(x)}{s d(y)} \beta_{x}$, where $\beta_{x}$ is the point estimate associated to control variable $x$, while $s d(x)$ and $s d(y)$ indicate the standard deviation or respectively control variable $x$ and dependent variable $y$. Robust standard errors are reported in parentheses. Robust standard errors are adjusted for clustering at the Congress member-level. A precise definition of control variables can be found in Table A1 in the appendix. The Wald $\chi^{2}$ test in column (3) evaluates the statistical difference of point estimates between variables 'Alumni Peers - Same Party ( 1 = Majority Abstained)' and 'Alumni Peers - Different Party ( 1 = Majority Abstained)'. The Wald $\chi^{2}$ test in column (4) evaluates the statistical difference of point estimates between variables 'Alumni Peers who are cosponsors ( $1=$ Majority Abstained)' and 'Alumni Peers who are not cosponsors $\left(1=\right.$ Majority Abstained)'. The Wald $\chi^{2}$ test in column (6) evaluates the statistical difference of point estimates between variables 'Alumni Peers ( 1 = Between $50 \%$ and $75 \%$ Abstained)' and 'Alumni Peers ( $1=$ Between $75 \%$ and $100 \%$ Abstained)'. *, **, *** indicate statistical significance at the 10,5 and 1 percent level. 
Table 4

\begin{tabular}{|c|c|c|c|c|c|}
\hline \multirow[b]{2}{*}{ Sample } & \multicolumn{5}{|c|}{$\begin{array}{l}\text { Dependent variable: Congress member } i \text { abstained on bill } j \\
\qquad(1=\text { Yes, } 0=\text { No })\end{array}$} \\
\hline & $\begin{array}{l}\text { All roll call } \\
\text { votes }\end{array}$ & $\begin{array}{l}\text { Roll call votes } \\
\text { relevant to the } \\
\text { Congress member }\end{array}$ & $\begin{array}{l}\text { Roll call votes } \\
\text { irrelevant to the } \\
\text { Congress member }\end{array}$ & $\begin{array}{c}\text { Roll call votes } \\
\text { irrelevant to the } \\
\text { Congress member: } \\
\text { vote closeness } \geq 0.8\end{array}$ & $\begin{array}{c}\text { Roll call votes } \\
\text { irrelevant to the } \\
\text { Congress member: } \\
\text { vote closeness }<0.8\end{array}$ \\
\hline & OLS & OLS & OLS & OLS & OLS \\
\hline & 1 & 2 & 3 & 4 & 5 \\
\hline Ideology Distance Differential & $\begin{array}{l}-0.0181 * * * \\
(0.0008)\end{array}$ & $\begin{array}{c}-0.0106^{* *} \\
(0.0039)\end{array}$ & $\begin{array}{l}-0.0182 * * * \\
(0.0008)\end{array}$ & $\begin{array}{c}-0.0030^{* *} \\
(0.0010)\end{array}$ & $\begin{array}{l}-0.0183 * * * \\
(0.0008)\end{array}$ \\
\hline Key vote $(1=$ Yes $)$ & $\begin{array}{c}-0.0142 * * * \\
(0.0012)\end{array}$ & $\begin{array}{l}-0.0176^{* * *} \\
(0.0043)\end{array}$ & $\begin{array}{c}-0.0142 * * * \\
(0.0012)\end{array}$ & $\begin{array}{l}-0.0159 * * * \\
(0.0016)\end{array}$ & $\begin{array}{c}-0.0141 * * * \\
(0.0012)\end{array}$ \\
\hline Vote closeness & $\begin{array}{l}-0.0344 * * * \\
(0.0012)\end{array}$ & $\begin{array}{l}-0.0558 * * * \\
(0.0075)\end{array}$ & $\begin{array}{l}-0.0342 * * * \\
(0.0012)\end{array}$ & $\begin{array}{c}-0.0070^{* * *} \\
(0.0009)\end{array}$ & $\begin{array}{l}-0.0352 * * * \\
(0.0014)\end{array}$ \\
\hline Individual fixed effects & Yes & Yes & Yes & Yes & Yes \\
\hline Congress fixed effects & Yes & Yes & Yes & Yes & Yes \\
\hline Roll call topic fixed effects & Yes & Yes & Yes & Yes & Yes \\
\hline $\mathrm{r} 2$ & 0.5364 & 0.5642 & 0.5362 & 0.4924 & 0.5665 \\
\hline Num. Obs. & $3,143,453$ & 42,464 & $3,100,989$ & $1,392,987$ & $1,708,002$ \\
\hline
\end{tabular}

Note: Results for model (3) of the paper. Standardized OLS estimated coefficients are reported. Standardization of coefficients is obtained using the formula $\frac{s d(x)}{s d(y)} \beta_{x}$, where $\beta_{x}$ is the point estimate associated to control variable $x$, while $s d(x)$ and $s d(y)$ indicate the standard deviation or respectively control variable $x$ and dependent variable $y$. Robust standard errors are reported in parentheses. Robust standard errors are adjusted for clustering at the Congress member-level. A precise definition of control variables can be found in Table A1 in the appendix. ${ }^{*}, * *, * *$ indicate statistical significance at the 10,5 and 1 percent level. 


\begin{tabular}{|c|c|c|c|c|c|c|c|c|}
\hline \multicolumn{9}{|c|}{ Table 5} \\
\hline Interaction variable & $\begin{array}{l}\text { Key vote } \\
(1=\text { Yes })\end{array}$ & $\begin{array}{l}\text { Close vote } \\
(1=\text { Yes })\end{array}$ & $\begin{array}{c}\text { Gender } \\
(1=\text { Female })\end{array}$ & $\begin{array}{c}\text { Race } \\
(1=\text { Not White })\end{array}$ & $\begin{array}{c}\text { Party } \\
(1=\text { Democrat })\end{array}$ & $\begin{array}{c}\text { Committee Chair } \\
(1=\text { Yes })\end{array}$ & DW Ideology & $\begin{array}{c}\text { Distance from } \\
\text { Washington D.C }\end{array}$ \\
\hline & OLS & OLS & OLS & OLS & OLS & OLS & OLS & OLS \\
\hline & 1 & 2 & 3 & 4 & 5 & 6 & 7 & 8 \\
\hline Alumni Peers ( 1 = Majority Abstained) & $\begin{array}{c}0.0194^{* * *} \\
(0.0020)\end{array}$ & $\begin{array}{c}0.0110^{* * *} \\
(0.0016)\end{array}$ & $\begin{array}{c}0.0107 * * * \\
(0.0013)\end{array}$ & $\begin{array}{c}0.0087^{* * *} \\
(0.0010)\end{array}$ & $\begin{array}{c}0.0056^{* * *} \\
(0.0013)\end{array}$ & $\begin{array}{c}0.0105^{* * *} \\
(0.0012)\end{array}$ & $\begin{array}{c}0.0094 * * \\
(0.0028)\end{array}$ & $\begin{array}{c}0.0083 * * * \\
(0.0018)\end{array}$ \\
\hline $\begin{array}{l}\text { Alumni Peers }(1=\text { Majority Abstained }) \text { * } \\
\text { interaction_variable }\end{array}$ & $\begin{array}{c}-0.0111 * * * \\
(0.0017)\end{array}$ & $\begin{array}{l}-0.0009 \\
(0.0014)\end{array}$ & $\begin{array}{l}-0.0009 \\
(0.0011)\end{array}$ & $\begin{array}{c}0.0035^{* *} \\
(0.0017)\end{array}$ & $\begin{array}{c}0.0064 * * * \\
(0.0016)\end{array}$ & $\begin{array}{l}-0.0009 \\
(0.0008)\end{array}$ & $\begin{array}{c}0.0010 \\
(0.0029)\end{array}$ & $\begin{array}{c}0.0026 \\
(0.0018)\end{array}$ \\
\hline interaction_variable & - & - & - & - & - & $\begin{array}{c}-0.0048^{*} \\
(0.0026)\end{array}$ & - & - \\
\hline Ideology Distance Differential & $\begin{array}{c}-0.0180 * * * \\
(0.0008)\end{array}$ & $\begin{array}{c}-0.0180 * * * \\
(0.0008)\end{array}$ & $\begin{array}{c}-0.0180 * * * \\
(0.0008)\end{array}$ & $\begin{array}{c}-0.0180^{* * *} \\
(0.0008)\end{array}$ & $\begin{array}{c}-0.0180 * * * \\
(0.0008)\end{array}$ & $\begin{array}{c}-0.0180 * * * \\
(0.0008)\end{array}$ & $\begin{array}{c}-0.0180 * * * \\
(0.0008)\end{array}$ & $\begin{array}{c}-0.0180 * * * \\
(0.0008)\end{array}$ \\
\hline Key vote $(1=$ Yes $)$ & $\begin{array}{c}-0.0134 * * * \\
(0.0012)\end{array}$ & $\begin{array}{c}-0.0141 * * * \\
(0.0012)\end{array}$ & $\begin{array}{c}-0.0141 * * * \\
(0.0012)\end{array}$ & $\begin{array}{c}-0.0141 * * * \\
(0.0012)\end{array}$ & $\begin{array}{c}-0.0141 * * * \\
(0.0012)\end{array}$ & $\begin{array}{c}-0.0140 * * * \\
(0.0012)\end{array}$ & $\begin{array}{c}-0.0141 * * * \\
(0.0012)\end{array}$ & $\begin{array}{c}-0.0141 * * * \\
(0.0012)\end{array}$ \\
\hline Vote closeness & $\begin{array}{c}-0.0341 * * * \\
(0.0012)\end{array}$ & $\begin{array}{c}-0.0341 * * * \\
(0.0012)\end{array}$ & $\begin{array}{c}-0.0341 * * * \\
(0.0012)\end{array}$ & $\begin{array}{c}-0.0341 * * * \\
(0.0012)\end{array}$ & $\begin{array}{c}-0.0341 * * * \\
(0.0012)\end{array}$ & $\begin{array}{c}-0.0341 * * * \\
(0.0012)\end{array}$ & $\begin{array}{c}-0.0341 * * * \\
(0.0012)\end{array}$ & $\begin{array}{c}-0.0341 * * * \\
(0.0012)\end{array}$ \\
\hline $\begin{array}{l}\text { Abstained more than once that day }(1= \\
\text { Yes) }\end{array}$ & $\begin{array}{c}0.7203^{* * *} \\
(0.0084)\end{array}$ & $\begin{array}{c}0.7204 * * * \\
(0.0084)\end{array}$ & $\begin{array}{c}0.7204^{* * *} \\
(0.0084)\end{array}$ & $\begin{array}{c}0.7203 * * * \\
(0.0084)\end{array}$ & $\begin{array}{c}0.7204 * * * \\
(0.0084)\end{array}$ & $\begin{array}{c}0.7203 * * * \\
(0.0084)\end{array}$ & $\begin{array}{c}0.7204 * * * \\
(0.0084)\end{array}$ & $\begin{array}{c}0.7204 * * * \\
(0.0084)\end{array}$ \\
\hline Thursday-Tuesday club $(1=$ Yes $)$ & $\begin{array}{c}-0.0255^{* * *} \\
(0.0013)\end{array}$ & $\begin{array}{c}-0.0255^{* * * *} \\
(0.0013)\end{array}$ & $\begin{array}{c}-0.0255^{* * * *} \\
(0.0013)\end{array}$ & $\begin{array}{c}-0.0255^{* * * *} \\
(0.0013)\end{array}$ & $\begin{array}{c}-0.0255^{* * *} \\
(0.0013)\end{array}$ & $\begin{array}{c}-0.0255^{* * * *} \\
(0.0013)\end{array}$ & $\begin{array}{c}-0.0255^{* * * *} \\
(0.0013)\end{array}$ & $\begin{array}{c}-0.0255^{* * * *} \\
(0.0013)\end{array}$ \\
\hline Individual fixed effects & Yes & Yes & Yes & Yes & Yes & Yes & Yes & Yes \\
\hline Congress fixed effects & Yes & Yes & Yes & Yes & Yes & Yes & Yes & Yes \\
\hline Roll call topic fixed effects & Yes & Yes & Yes & Yes & Yes & Yes & Yes & Yes \\
\hline $\mathrm{r} 2$ & 0.5364 & 0.5364 & 0.5364 & 0.5364 & 0.5364 & 0.5364 & 0.5364 & 0.5364 \\
\hline Num. Obs. & $3,143,453$ & $3,143,453$ & $3,143,453$ & $3,143,453$ & $3,143,453$ & $3,143,453$ & $3,143,453$ & $3,143,453$ \\
\hline
\end{tabular}

Note: Results for model (4) of the paper. Standardized OLS estimated coefficients are reported. Standardization of coefficients is obtained using the formula $\frac{s d(x)}{s d(y)} \beta_{x}$, where $\beta_{x}$ is the point

estimate associated to control variable $x$, while $s d(x)$ and $s d(y)$ indicate the standard deviation or respectively control variable $x$ and dependent variable $y$. Robust standard errors are reported in parentheses. Robust standard errors are adjusted for clustering at the Congress member-level. A precise definition of control variables can be found in Table A1 in the appendix. $*, * *, * * *$ indicate statistical significance at the 10,5 and 1 percent level. 
Fig. 1: Congress members by topic subject of interest

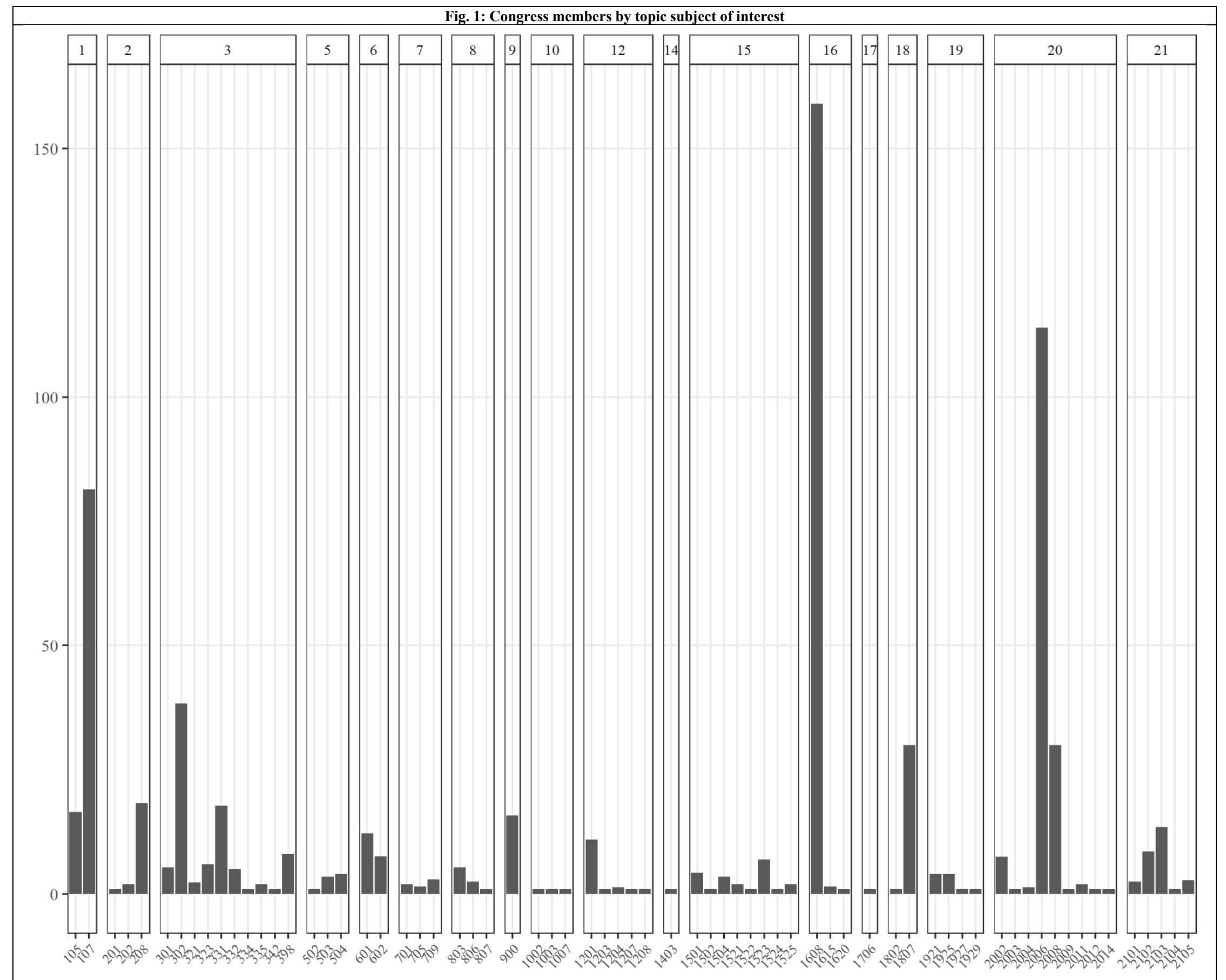

Note: The $\mathrm{x}$-axis reports the PAP Code relative to the topic subject of the bills sponsored or cosponsored by Congress members. Topic subjects are grouped according to their policy area, reported on top of the plot. The y-axis shows the average number of Congress members who have a particular interest on a topic subject in Congresses $109^{\text {th }}-113^{\text {th }}$. The PAP topic subjects for which no Congress member had a specific interest in any considered Congress are not reported. A precise definition of the policy content related to a PAP code is indicated in Table A4. 


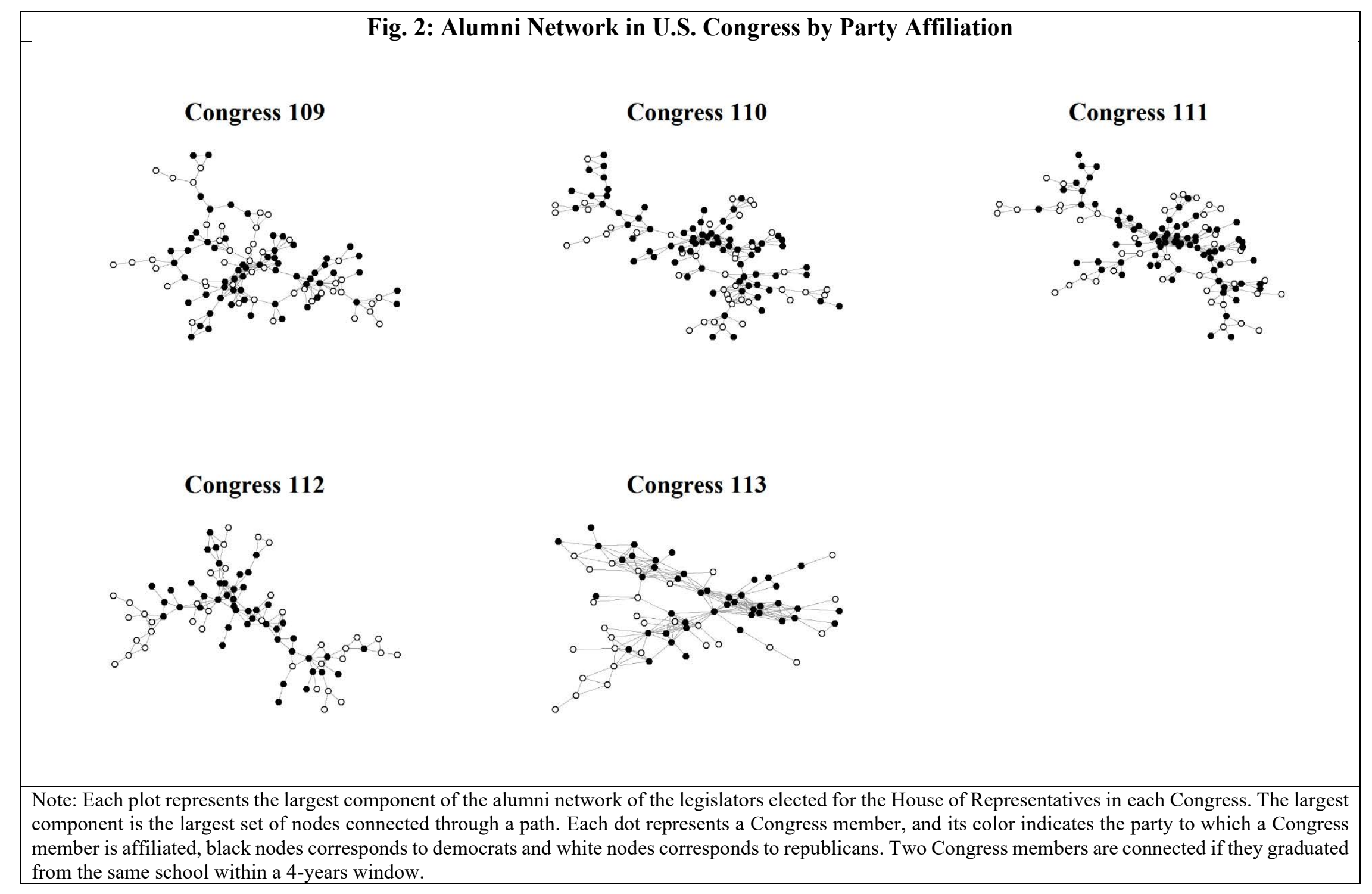




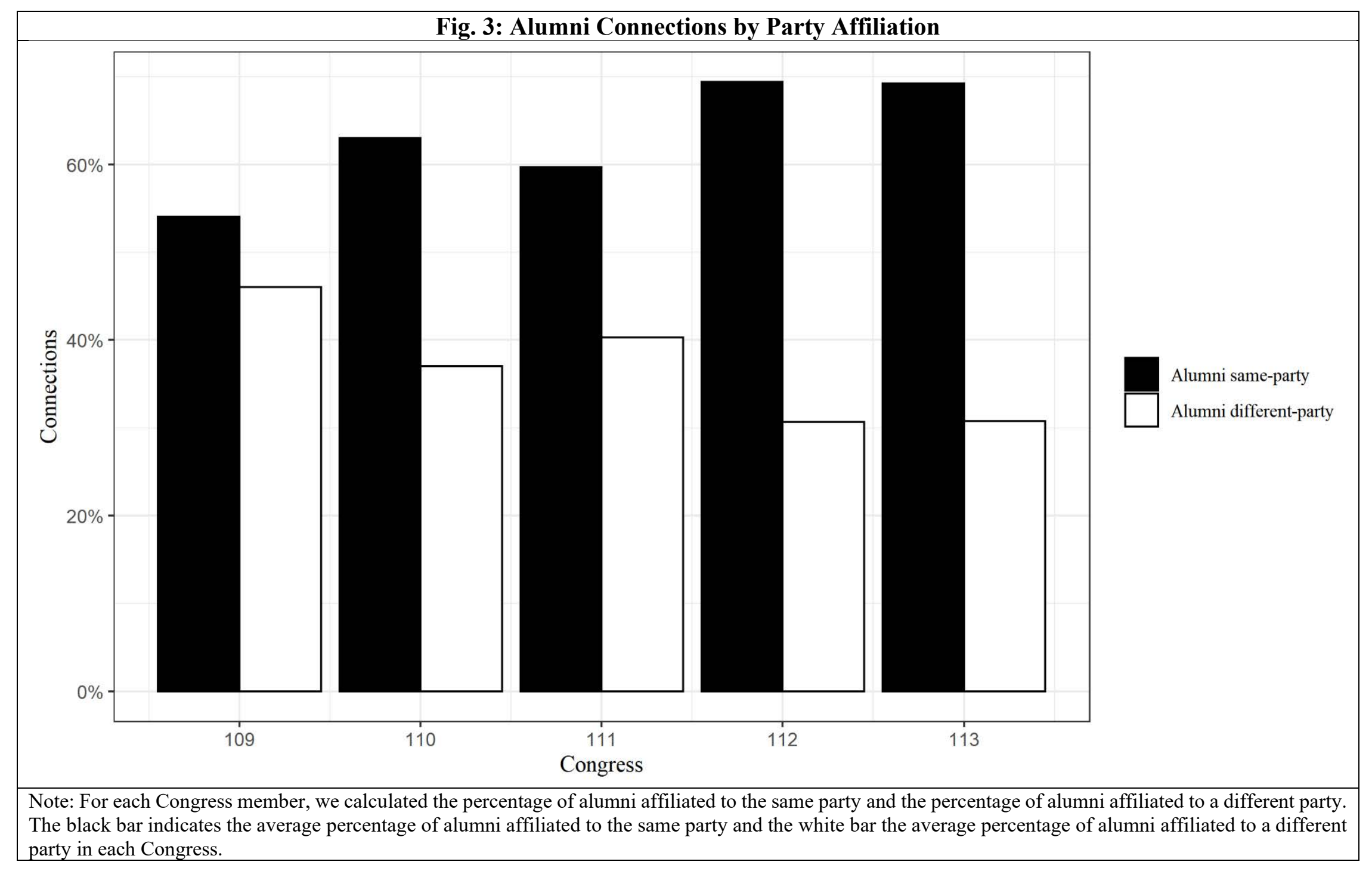




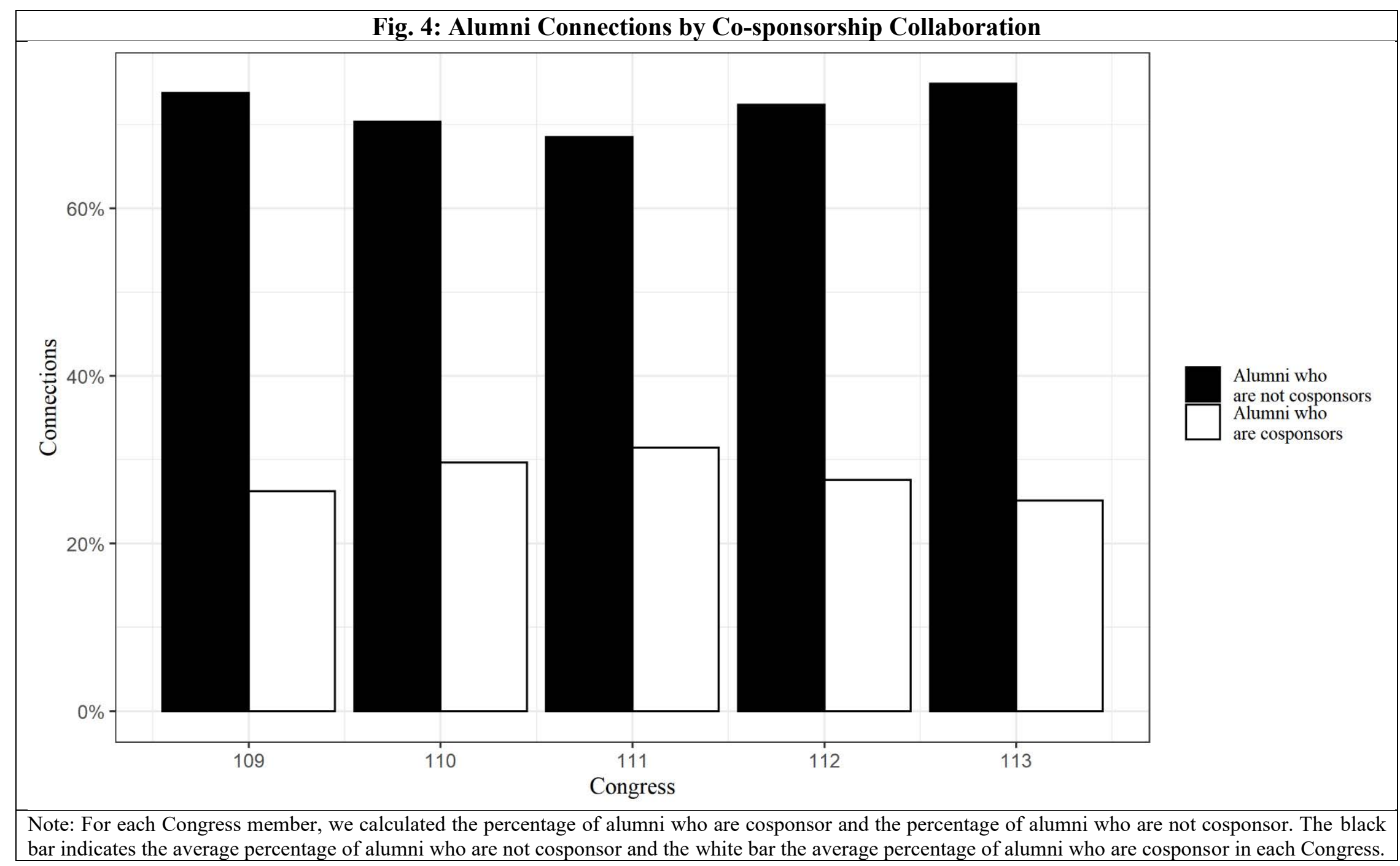




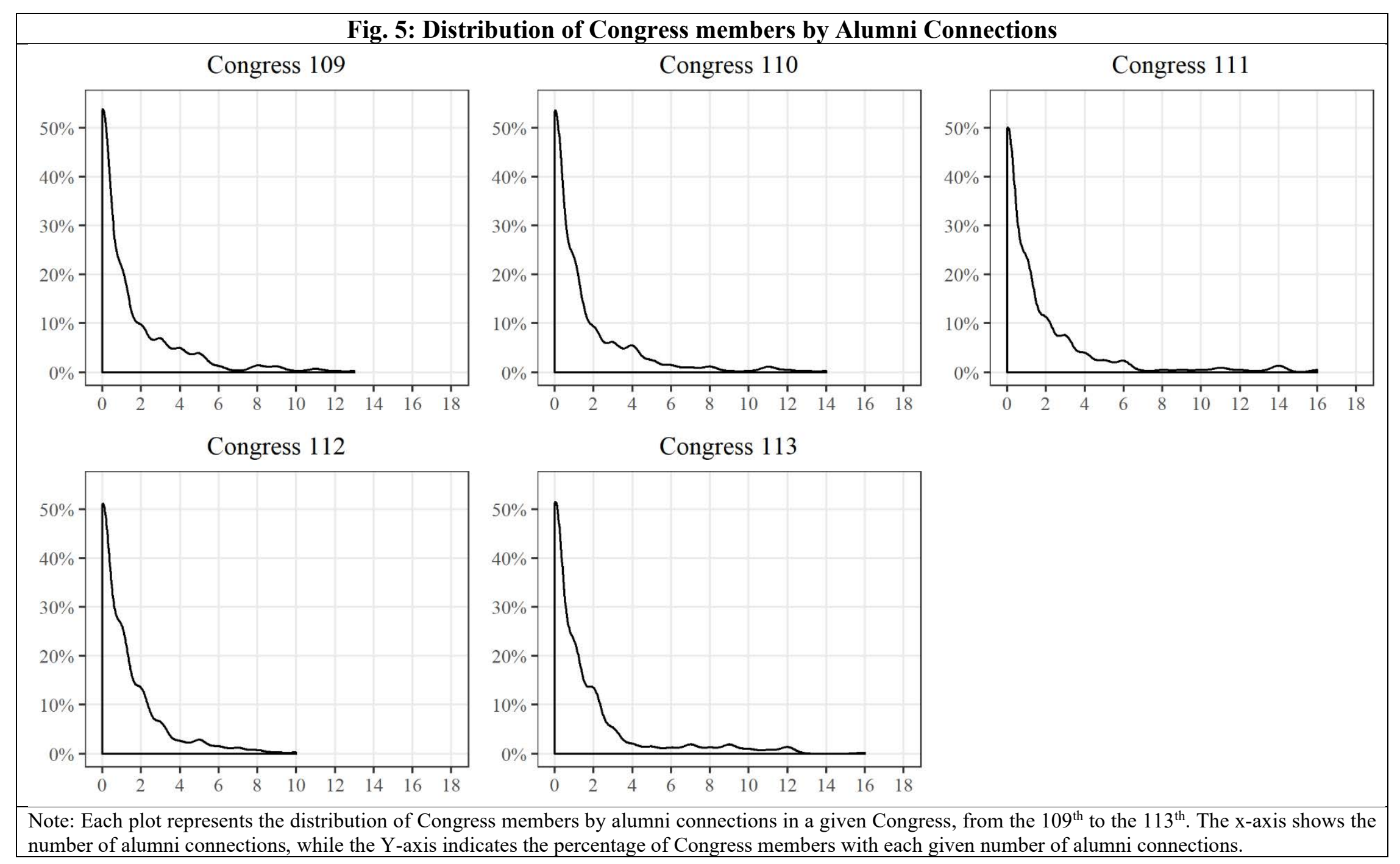




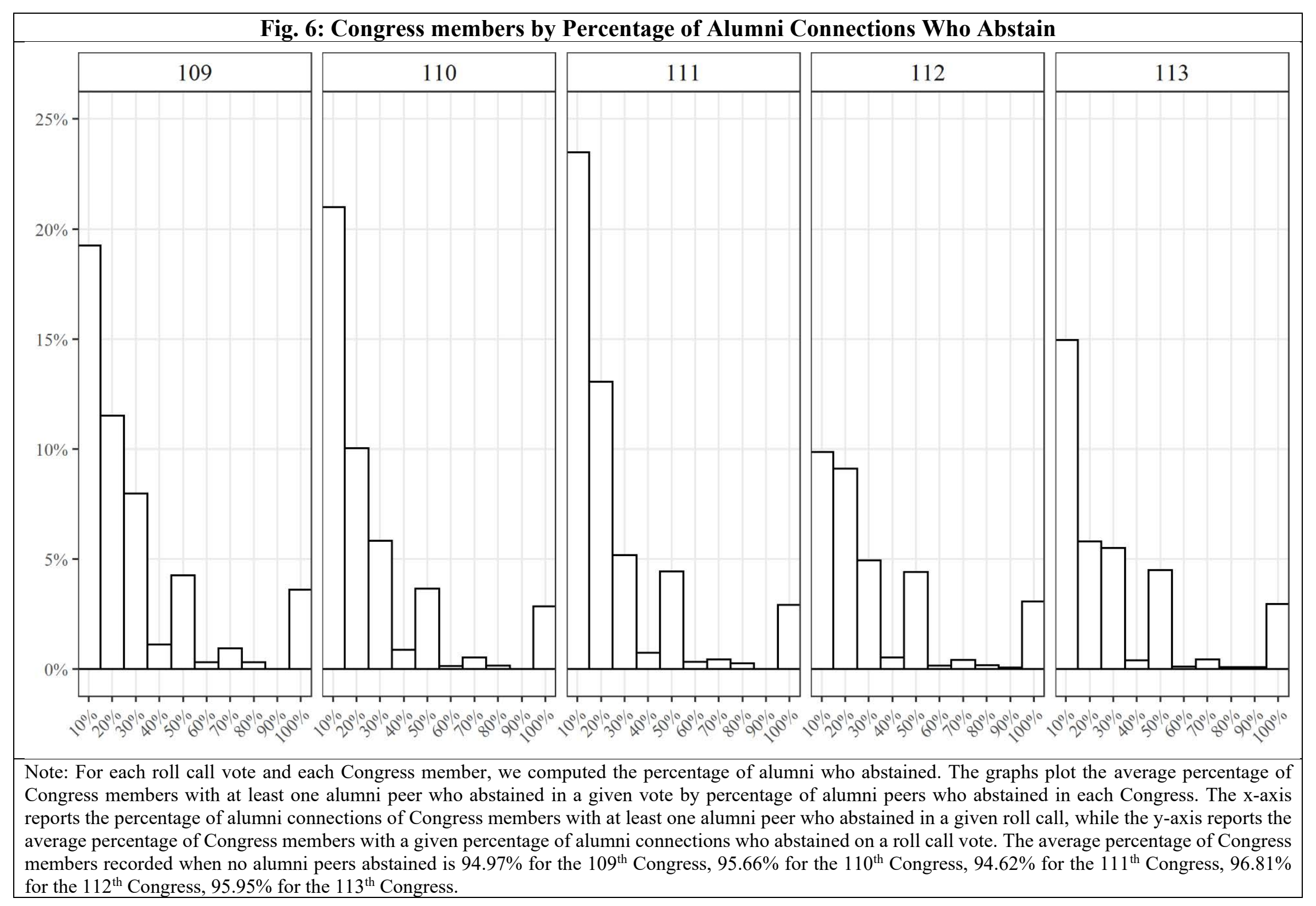




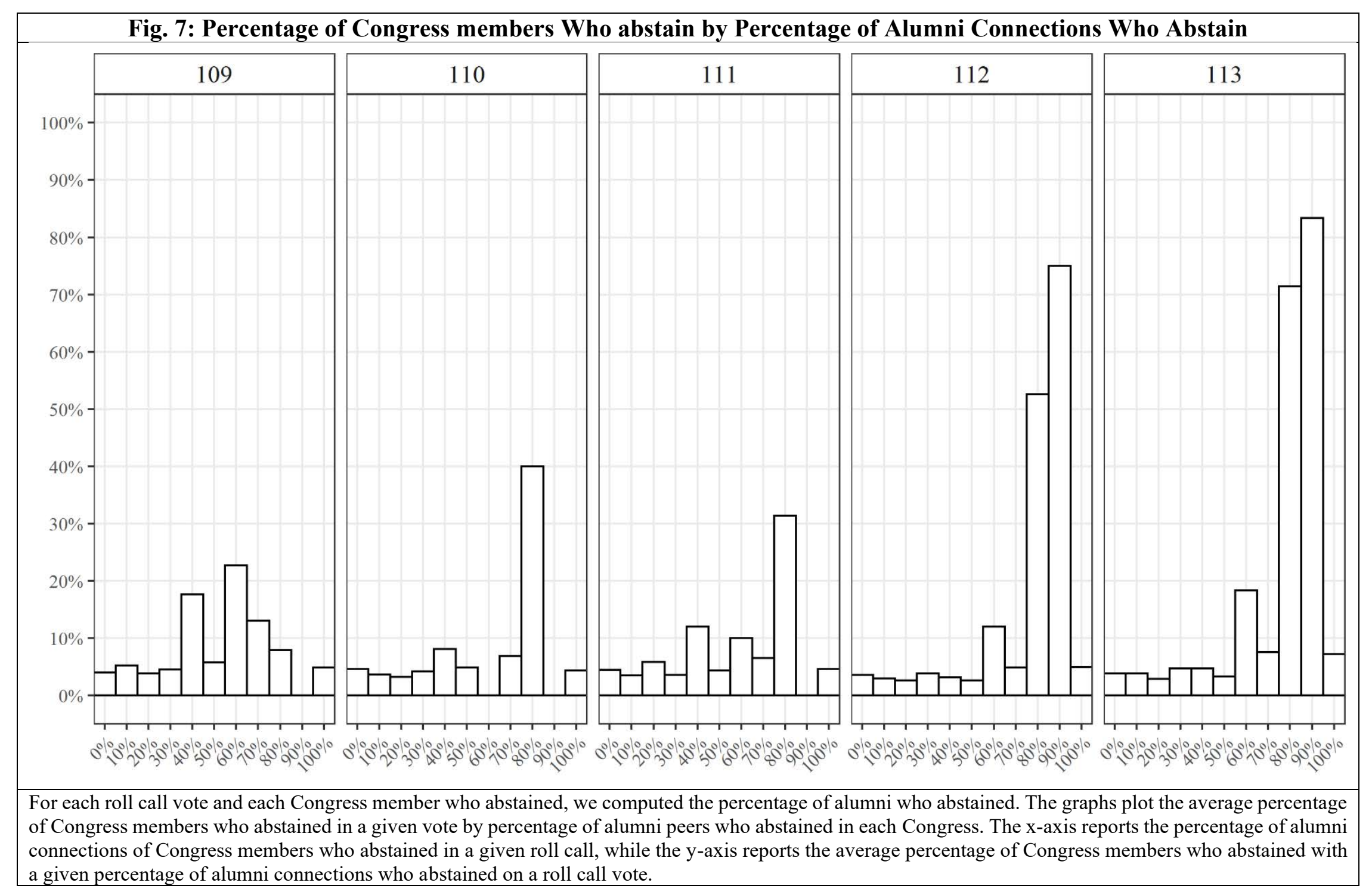




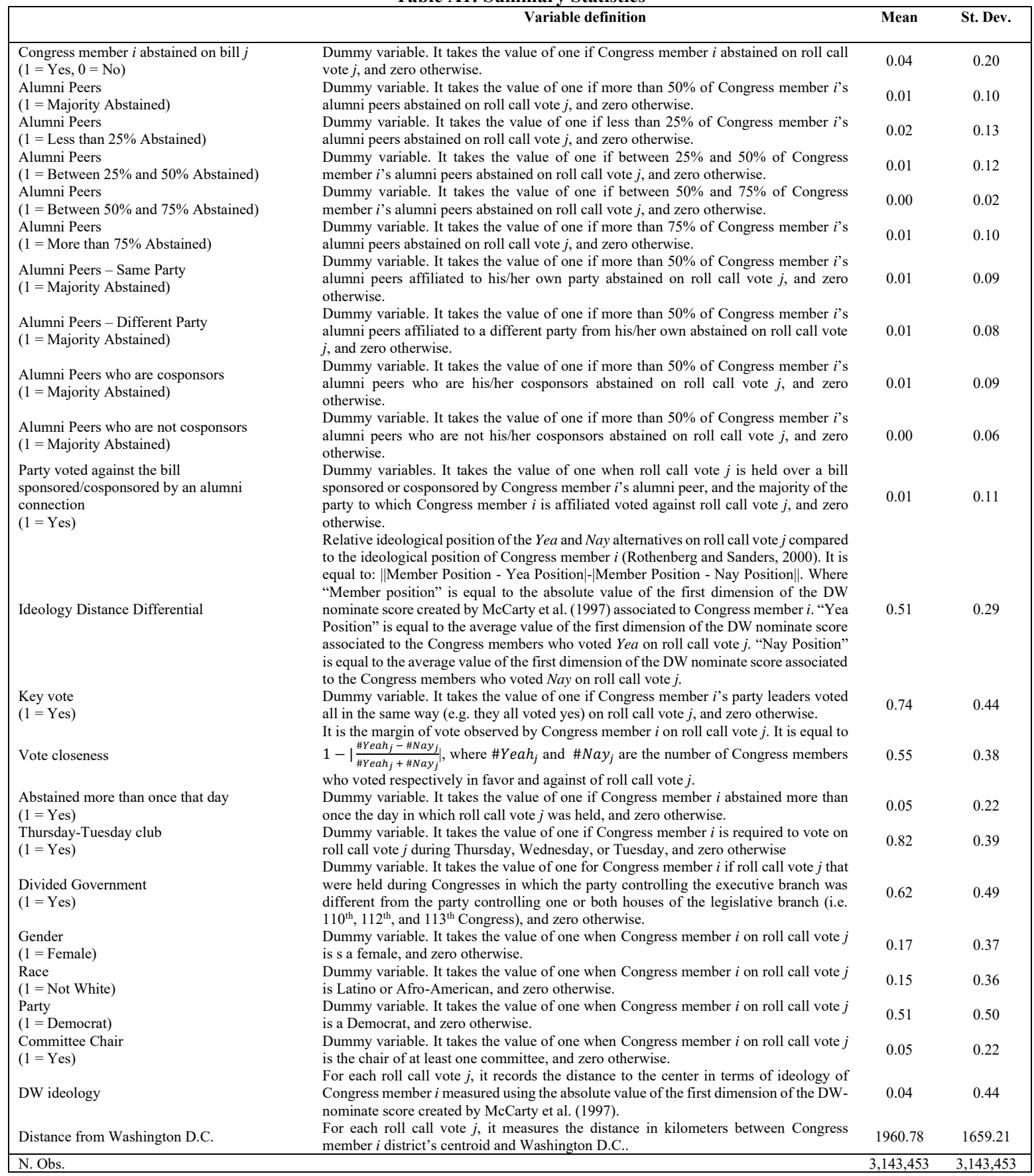


Table A2

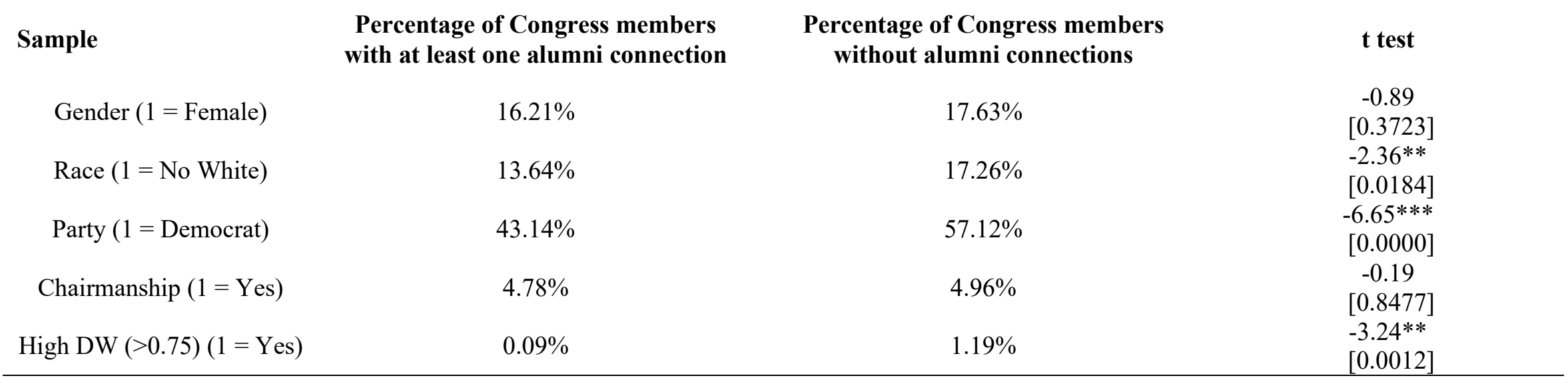


Table A3

\begin{tabular}{|c|c|c|c|c|c|c|}
\hline & & $\frac{\text { ble A3 }}{\text { Depende }}$ & $\begin{array}{l}\text { ariable: Con } \\
\qquad(1=\end{array}$ & $\begin{array}{l}\text { s member } i \text { a } \\
, 0=\text { No) }\end{array}$ & ained on bill $j$ & \\
\hline & OLS & OLS & OLS & OLS & OLS & OLS \\
\hline & 1 & 2 & 3 & 4 & 5 & 6 \\
\hline Alumni Peers ( 1 = Majority Abstained) & & $\begin{array}{c}0.0163 * * * \\
(0.0017)\end{array}$ & & & $\begin{array}{c}0.0082 * * * \\
(0.0015)\end{array}$ & \\
\hline Alumni Peers - Same Party (1 = Majority Abstained) & & & $\begin{array}{c}0.0143 * * * \\
(0.0021)\end{array}$ & & & \\
\hline Alumni Peers - Different Party ( 1 = Majority Abstained) & & & $\begin{array}{c}0.0067 * * * \\
(0.0010)\end{array}$ & & & \\
\hline Alumni Peers who are cosponsors ( 1 = Majority Abstained $)$ & & & & $\begin{array}{c}0.0131 * * * \\
(0.0018)\end{array}$ & & \\
\hline Alumni Peers who are not cosponsors $(1=$ Majority Abstained $)$ & & & & $\begin{array}{c}0.0069 * * * \\
(0.0015)\end{array}$ & & \\
\hline Alumni Peers ( $1=$ Between $0 \%$ and $25 \%$ Abstained $)$ & & & & & & $\begin{array}{c}0.0002 \\
(0.0009)\end{array}$ \\
\hline Alumni Peers $(1=$ Between $25 \%$ and $50 \%$ Abstained $)$ & & & & & & $\begin{array}{c}0.0010 \\
(0.0011)\end{array}$ \\
\hline Alumni Peers $(1=$ Between $50 \%$ and $75 \%$ Abstained $)$ & & & & & & $\begin{array}{c}0.0057 * * * \\
(0.0013)\end{array}$ \\
\hline Alumni Peers ( 1 = Between 75\% and 100\% Abstained) & & & & & & $\begin{array}{c}0.0071 * * * \\
(0.0015)\end{array}$ \\
\hline Ideology Distance Differential & $\begin{array}{c}-0.0089 * * * \\
(0.0011)\end{array}$ & $\begin{array}{c}-0.0087 * * * \\
(0.0011)\end{array}$ & $\begin{array}{c}-0.0087 * * * \\
(0.0011)\end{array}$ & $\begin{array}{c}-0.0087 * * * \\
(0.0011)\end{array}$ & $\begin{array}{l}0.0021^{*} \\
(0.0012)\end{array}$ & $\begin{array}{l}0.0022 * \\
(0.0012)\end{array}$ \\
\hline Key vote $(1=$ Yes $)$ & $\begin{array}{c}-0.0108 * * * \\
(0.0016)\end{array}$ & $\begin{array}{c}-0.0104 * * * \\
(0.0016)\end{array}$ & $\begin{array}{c}-0.0104 * * * \\
(0.0016)\end{array}$ & $\begin{array}{c}-0.0104 * * * \\
(0.0016)\end{array}$ & $\begin{array}{c}-0.0098 * * * \\
(0.0017)\end{array}$ & $\begin{array}{c}-0.0098 * * * \\
(0.0017)\end{array}$ \\
\hline Vote closeness & $\begin{array}{c}-0.0267 * * * \\
(0.0015)\end{array}$ & $\begin{array}{c}-0.0263 * * * \\
(0.0015)\end{array}$ & $\begin{array}{c}-0.0263 * * * \\
(0.0015)\end{array}$ & $\begin{array}{c}-0.0263 * * * \\
(0.0015)\end{array}$ & $\begin{array}{c}-0.0030 * * * \\
(0.0007)\end{array}$ & $\begin{array}{c}-0.0030 * * * \\
(0.0007)\end{array}$ \\
\hline Abstained more than once that day $(1=$ Yes $)$ & $\begin{array}{c}0.7180^{* * *} \\
(0.0120)\end{array}$ & $\begin{array}{c}0.7177 * * * \\
(0.0120)\end{array}$ & $\begin{array}{c}0.7177 * * * \\
(0.0120)\end{array}$ & $\begin{array}{c}0.7177 * * * \\
(0.0120)\end{array}$ & $\begin{array}{c}0.7221 * * * \\
(0.0117)\end{array}$ & $\begin{array}{c}0.7221 * * * \\
(0.0117)\end{array}$ \\
\hline Thursday-Tuesday club ( 1 = Yes) & $\begin{array}{c}-0.0272 * * * \\
(0.0019)\end{array}$ & $\begin{array}{c}-0.0265^{* * *} \\
(0.0018)\end{array}$ & $\begin{array}{c}-0.0264 * * * \\
(0.0018)\end{array}$ & $\begin{array}{c}-0.0265^{* * *} \\
(0.0018)\end{array}$ & $\begin{array}{c}-0.0099 * * * \\
(0.0024)\end{array}$ & $\begin{array}{c}-0.0099 * * * \\
(0.0024)\end{array}$ \\
\hline $\begin{array}{l}\text { Wald } \chi^{2} \text { test } \\
\text { [p-value] }\end{array}$ & & & $\begin{array}{c}8.20 * * \\
{[0.0042]}\end{array}$ & $\begin{array}{c}0.32 \\
{[0.5700]}\end{array}$ & & $\begin{array}{c}9.50 * * \\
{[0.0021]}\end{array}$ \\
\hline Individual fixed effects & Yes & Yes & Yes & Yes & Yes & Yes \\
\hline Congress fixed effects & Yes & Yes & Yes & Yes & No & No \\
\hline Roll call topic fixed effects & Yes & Yes & Yes & Yes & Yes & Yes \\
\hline Bill fixed effect & No & No & No & No & Yes & Yes \\
\hline $\mathrm{r} 2$ & 0.5391 & 0.5393 & 0.5393 & 0.5392 & 0.5513 & 0.5513 \\
\hline Num. Obs. & $1,551,961$ & $1,551,961$ & $1,551,961$ & $1,551,961$ & $1,551,961$ & $1,551,961$ \\
\hline
\end{tabular}

Note: Results for model (1) of the paper are in columns (1) - (4). Results for model (2) are in columns (5) - (6). Standardized OLS estimated coefficients are reported. Standardization of coefficients is obtained using the formula $\frac{s d(x)}{s d(y)} \beta_{x}$, where $\beta_{x}$ is the point estimate associated to control variable $x$, while $s d(x)$ and $s d(y)$ indicate the standard deviation or respectively control variable $x$ and dependent variable $y$. Robust standard errors are reported in parentheses. Robust standard errors are adjusted for clustering at the Congress member-level. A precise definition of control variables can be found in Table A1 in the appendix. The Wald $\chi^{2}$ test in columns (3) evaluates the statistical difference of point estimates between variables 'Alumni Peers - Same Party $(1$ = Majority Abstained)' and 'Alumni Peers - Different Party ( 1 = Majority Abstained)'. The Wald $\chi^{2}$ test in column (4) evaluates the statistical difference of point estimates between variables 'Alumni Peers who are cosponsors $(1=$ Majority Abstained)' and 'Alumni Peers who are not cosponsors ( 1 = Majority Abstained)'. Results are obtained using the vote records of the Congress members who have at least one alumni connection. $*, * *, * * *$ indicate statistical significance at the 10,5 and 1 percent level. 
Table A4 - PAP Categories

\begin{tabular}{|c|c|c|c|c|}
\hline \multicolumn{2}{|r|}{ Major Policy Area } & \multicolumn{3}{|c|}{ Topic Subject } \\
\hline PAP Code & Content & PAP Code & Content & Description \\
\hline \multirow{8}{*}{1} & \multirow{8}{*}{$\begin{array}{l}\text { Includes issues related to general } \\
\text { domestic macroeconomic policy }\end{array}$} & 101 & Interest Rates & Includes issues related to inflation, cost of living, prices, and interest rates \\
\hline & & 103 & Unemployment Rate & Includes issues related to the unemployment rate, impact of unemployment \\
\hline & & 104 & Monetary Policy & Includes issues related to the monetary policy, central bank, and the treasury \\
\hline & & 105 & National Budget & Issues related to public debt, budgeting, and efforts to reduce deficits \\
\hline & & 107 & Tax Code & Includes issues related to tax policy, the impact of taxes, and tax enforcement \\
\hline & & 108 & Industrial Policy & Includes issues related to manufacturing policy, industrial revitalization and growth \\
\hline & & 110 & Price Control & Includes issues related to wage or price control, emergency price controls \\
\hline & & 199 & Other & Includes issues related to other macroeconomics subtopics \\
\hline \multirow{9}{*}{2} & \multirow{9}{*}{$\begin{array}{l}\text { Includes issues related generally } \\
\text { to civil rights and minority rights }\end{array}$} & 201 & $\begin{array}{l}\text { Minority } \\
\text { Discrimination }\end{array}$ & Includes issues related to minority, ethnic, and racial group discrimination \\
\hline & & 202 & $\begin{array}{l}\text { Gender } \\
\text { Discrimination }\end{array}$ & Includes issues related to sex, gender, and sexual orientation discrimination \\
\hline & & 204 & Age Discrimination & $\begin{array}{l}\text { Includes issues related to age discrimination, including mandatory retirement age } \\
\text { policies }\end{array}$ \\
\hline & & 205 & $\begin{array}{l}\text { Handicap } \\
\text { Discrimination }\end{array}$ & Includes issues related to handicap and disease discrimination \\
\hline & & 206 & Voting Rights & $\begin{array}{l}\text { Includes issues related to voting rights, expanding or contracting the franchise, } \\
\text { participation and related issues }\end{array}$ \\
\hline & & 207 & Freedom of Speech & $\begin{array}{l}\text { Issues related to freedom of speech, religious freedoms, and other types of freedom of } \\
\text { expression }\end{array}$ \\
\hline & & 208 & Right to Privacy & $\begin{array}{l}\text { Includes issues related to privacy rights, including privacy of records, access to } \\
\text { government information, and abortion rights }\end{array}$ \\
\hline & & 209 & Anti-Government & $\begin{array}{l}\text { Includes issues related to anti-government activity groups, such as the communist } \\
\text { party and local insurgency groups }\end{array}$ \\
\hline & & 299 & Other & Includes issues related to other civil rights subtopics \\
\hline \multirow{11}{*}{3} & \multirow{11}{*}{$\begin{array}{l}\text { Includes issues related generally } \\
\text { to health care, including } \\
\text { appropriations for general health } \\
\text { care government agencies }\end{array}$} & 301 & Health Care Reform & Includes issues related to broad, comprehensive changes in the health care system \\
\hline & & 302 & Insurance & Includes issues related to health insurance reform, regulation, availability, and cost \\
\hline & & 321 & Drug Industry & $\begin{array}{l}\text { Includes issues related to the regulation and promotion of pharmaceuticals, medical } \\
\text { devices, and clinical labs }\end{array}$ \\
\hline & & 322 & Medical Facilities & $\begin{array}{l}\text { Issues related to facilities construction, regulation and payments, including waitlists } \\
\text { and ambulance services }\end{array}$ \\
\hline & & 323 & Insurance Providers & $\begin{array}{l}\text { Includes issues related to provider and insurer payments and regulation, including } \\
\text { other types of benefits or multiple benefits }\end{array}$ \\
\hline & & 324 & Medical Liability & $\begin{array}{l}\text { Includes issues related to medical liability, malpractice issues, medical fraud and } \\
\text { abuse, and unfair practices }\end{array}$ \\
\hline & & 325 & Manpower & $\begin{array}{l}\text { Issues related to the supply and quantity of labor in the health care industry, training } \\
\text { and licensing }\end{array}$ \\
\hline & & 331 & Disease Prevention & $\begin{array}{l}\text { Issues related to disease prevention, treatment, and health promotion, including } \\
\text { specific diseases not covered in other subtopics }\end{array}$ \\
\hline & & 332 & Infants and Children & $\begin{array}{l}\text { Includes issues related to infants and children, including coverage and quality of care, } \\
\text { health promotion, and school health programs }\end{array}$ \\
\hline & & 333 & Mental & Includes issues related to mental health care and mental health disease \\
\hline & & 334 & Long-term Care & $\begin{array}{l}\text { Includes issues related to long term care, home health care, the terminally ill, and } \\
\text { rehabilitation services }\end{array}$ \\
\hline
\end{tabular}




\begin{tabular}{|c|c|c|c|c|}
\hline & & 335 & $\begin{array}{l}\text { Drug Coverage and } \\
\text { Cost }\end{array}$ & $\begin{array}{l}\text { Includes issues related to prescription drug coverage, programs to pay for prescription } \\
\text { drugs, and policy to reduce the cost of prescription drugs }\end{array}$ \\
\hline & & 341 & Tobacco Abuse & Includes issues related to tobacco abuse, treatment, education, and health effects \\
\hline & & 342 & $\begin{array}{l}\text { Drug and Alcohol } \\
\text { Abuse }\end{array}$ & $\begin{array}{l}\text { Includes issues related to alcohol and illegal drug abuse, treatment, education, and } \\
\text { health effects }\end{array}$ \\
\hline & & 398 & $\mathrm{R} \& \mathrm{D}$ & Includes issues related to health care research and development \\
\hline & & 399 & Other & Includes issues related to other health care topics \\
\hline \multirow{8}{*}{4} & \multirow{8}{*}{$\begin{array}{l}\text { Includes issues related to general } \\
\text { agriculture policy, including } \\
\text { appropriations for general } \\
\text { agriculture government agencies }\end{array}$} & 401 & Trade & Includes issues related to the regulation and impact of agricultural foreign trade \\
\hline & & 402 & Subsidies to Farmers & $\begin{array}{l}\text { Includes issues related to government subsidies to farmers and ranchers, including } \\
\text { agricultural disaster insurance }\end{array}$ \\
\hline & & 403 & $\begin{array}{l}\text { Food Inspection \& } \\
\text { Safety }\end{array}$ & $\begin{array}{l}\text { Includes issues related to food inspection and safety, including seafood, and labeling } \\
\text { requirements }\end{array}$ \\
\hline & & 404 & $\begin{array}{l}\text { Marketing \& } \\
\text { Promotion }\end{array}$ & $\begin{array}{l}\text { Includes issues related to efforts to provide information on agricultural products to } \\
\text { consumers and the regulation of agricultural marketing }\end{array}$ \\
\hline & & 405 & $\begin{array}{l}\text { Animal and Crop } \\
\text { Disease }\end{array}$ & $\begin{array}{l}\text { Includes issues related to animal and crop disease, pest control and pesticide } \\
\text { regulation, and welfare for domesticated animals }\end{array}$ \\
\hline & & 408 & Fisheries \& Fishing & Includes issues related to fishing, commercial fishery regulation and conservation \\
\hline & & 498 & $\mathrm{R} \& \mathrm{D}$ & Includes issues related to agricultural research and development \\
\hline & & 499 & Other & Includes issues related to other agricultural subtopics \\
\hline \multirow{8}{*}{5} & \multirow{8}{*}{$\begin{array}{l}\text { Includes issues generally related } \\
\text { to labor, employment, and } \\
\text { pensions, including } \\
\text { appropriations for government } \\
\text { agencies regulating labor policy }\end{array}$} & 501 & Worker Safety & $\begin{array}{l}\text { Includes issues related to worker safety and protection and compensation for work- } \\
\text { related injury and disease }\end{array}$ \\
\hline & & 502 & $\begin{array}{l}\text { Employment } \\
\text { Training }\end{array}$ & $\begin{array}{l}\text { Includes issues related to job training for adult workers, workforce development, and } \\
\text { efforts to retrain displaced workers }\end{array}$ \\
\hline & & 503 & Employee Benefits & $\begin{array}{l}\text { Includes issues related to all employee benefits, pensions, and retirement accounts, } \\
\text { including government-provided unemployment insurance }\end{array}$ \\
\hline & & 504 & Labor Unions & $\begin{array}{l}\text { Includes issues related to labor unions, collective bargaining, and employer-employee } \\
\text { relations }\end{array}$ \\
\hline & & 505 & Fair Labor Standards & $\begin{array}{l}\text { Includes issues related to fair labor standards such as the minimum wage and overtime } \\
\text { compensation, and labor law }\end{array}$ \\
\hline & & 506 & Youth Employment & Includes issues related to youth employment, child labor and job training for youths \\
\hline & & 529 & Migrant and Seasonal & Includes issues related to migrant, guest and seasonal workers \\
\hline & & 599 & Other & Issues related to other labor policy \\
\hline \multirow{8}{*}{6} & \multirow{8}{*}{$\begin{array}{l}\text { Includes issues related to general } \\
\text { education policy, including } \\
\text { appropriations for government } \\
\text { agencies regulating education } \\
\text { policy }\end{array}$} & 601 & Higher & $\begin{array}{l}\text { Includes issues related to higher education, student loans and education finance, and } \\
\text { the regulation of colleges and universities }\end{array}$ \\
\hline & & 602 & $\begin{array}{l}\text { Elementary \& } \\
\text { Secondary }\end{array}$ & $\begin{array}{l}\text { Includes issues related to elementary and primary schools, school reform, safety in } \\
\text { schools, and efforts to generally improve educational standards and outcomes }\end{array}$ \\
\hline & & 603 & Underprivileged & $\begin{array}{l}\text { Includes issues related to education of underprivileged students, including adult } \\
\text { literacy programs, bilingual education needs, and rural education initiatives }\end{array}$ \\
\hline & & 604 & Vocational & Includes issues related to vocational education for children and adults and their impact \\
\hline & & 606 & Special & $\begin{array}{l}\text { Includes issues related to special education and education for the physically or } \\
\text { mentally handicapped }\end{array}$ \\
\hline & & 607 & Excellence & $\begin{array}{l}\text { Includes issues related to education excellence, including efforts to increase the quality } \\
\text { of specific areas, such as math, science or foreign language skills }\end{array}$ \\
\hline & & 698 & $\mathrm{R} \& \mathrm{D}$ & Includes issues related to research and development in education \\
\hline & & 699 & Other & Includes issues related to other subtopics in education policy \\
\hline \multirow{2}{*}{7} & \multirow{2}{*}{$\begin{array}{l}\text { Includes issues related to general } \\
\text { environmental policy, including } \\
\text { appropriations for government }\end{array}$} & 701 & Drinking Water & $\begin{array}{l}\text { Includes issues related to domestic drinking water safety, supply, pollution, } \\
\text { fluoridation, and conservation }\end{array}$ \\
\hline & & 703 & Waste Disposal & $\begin{array}{l}\text { Includes issues related to the disposal and treatment of wastewater, solid waste and } \\
\text { runoff. }\end{array}$ \\
\hline
\end{tabular}




\begin{tabular}{|c|c|c|c|c|}
\hline & \multirow[t]{8}{*}{$\begin{array}{l}\text { agencies regulating environmental } \\
\text { policy }\end{array}$} & 704 & Hazardous Waste & $\begin{array}{l}\text { Includes issues related to hazardous waste and toxic chemical regulation, treatment, } \\
\text { and disposal }\end{array}$ \\
\hline & & 705 & Air Pollution & Includes issues related to air pollution, climate change, and noise pollution \\
\hline & & 707 & Recycling & Includes issues related to recycling, reuse, and resource conservation \\
\hline & & 708 & Indoor Hazards & $\begin{array}{l}\text { Includes issues related to indoor environmental hazards, indoor air contamination } \\
\text { (including on airlines), and indoor hazardous substances such as asbestos }\end{array}$ \\
\hline & & 709 & Species \& Forest & $\begin{array}{l}\text { Includes issues related to species and forest protection, endangered species, control of } \\
\text { the domestic illicit trade in wildlife products, and regulation of laboratory or } \\
\text { performance animals }\end{array}$ \\
\hline & & 711 & Conservation & Includes issues related to land and water conservation \\
\hline & & 798 & $\mathrm{R} \& \mathrm{D}$ & $\begin{array}{l}\text { Includes issues related to research and development in environmental technology, not } \\
\text { including alternative energy }\end{array}$ \\
\hline & & 799 & Other & Includes issues related to other environmental subtopics \\
\hline \multirow{8}{*}{8} & \multirow{8}{*}{$\begin{array}{l}\text { Includes issues generally related } \\
\text { to energy policy, including } \\
\text { appropriations for government } \\
\text { agencies regulating energy policy }\end{array}$} & 801 & Nuclear & $\begin{array}{l}\text { Includes issues related to nuclear energy, safety and security, and disposal of nuclear } \\
\text { waste }\end{array}$ \\
\hline & & 802 & Electricity & $\begin{array}{l}\text { Includes issues related to to general electricity, hydropower, and regulation of } \\
\text { electrical utilities }\end{array}$ \\
\hline & & 803 & Natural Gas \& Oil & $\begin{array}{l}\text { Includes issues related to natural gas and oil, drilling, oil spills and flaring, oil and gas } \\
\text { prices, shortages and gasoline regulation }\end{array}$ \\
\hline & & 805 & Coal & $\begin{array}{l}\text { Includes issues related to coal production, use, trade, and regulation, including coal } \\
\text { gasification and clean coal technologies }\end{array}$ \\
\hline & & 806 & $\begin{array}{l}\text { Alternative \& } \\
\text { Renewable }\end{array}$ & $\begin{array}{l}\text { Includes issues related to alternative and renewable energy, biofuels, hydrogen and } \\
\text { geothermal power }\end{array}$ \\
\hline & & 807 & Conservation & $\begin{array}{l}\text { Includes issues related to energy conservation and energy efficiency, including } \\
\text { vehicles, homes, commercial use and government }\end{array}$ \\
\hline & & 898 & $\mathrm{R} \& \mathrm{D}$ & Includes issues related to energy research and development \\
\hline & & 899 & Other & Includes issues related to other energy subtopics \\
\hline 9 & Immigration & 900 & General & Includes issues related to immigration, refugees, and citizenship \\
\hline \multirow{8}{*}{10} & \multirow{8}{*}{$\begin{array}{l}\text { Includes issues related generally } \\
\text { to transportation, including } \\
\text { appropriations for government } \\
\text { agencies regulating transportation } \\
\text { policy }\end{array}$} & 1001 & Mass & $\begin{array}{l}\text { Includes issues related to mass transportation construction, regulation, safety, and } \\
\text { availability }\end{array}$ \\
\hline & & 1002 & Highways & Includes issues related to public highway construction, maintenance, and safety \\
\hline & & 1003 & Air Travel & $\begin{array}{l}\text { Includes issues related to air travel, regulation and safety of aviation, airports, air traffic } \\
\text { control, pilot training, and aviation technology }\end{array}$ \\
\hline & & 1005 & Railroad Travel & $\begin{array}{l}\text { Includes issues related to railroads, rail travel, rail freight, and the development and } \\
\text { deployment of new rail technologies }\end{array}$ \\
\hline & & 1007 & Maritime & $\begin{array}{l}\text { Includes issues related to maritime transportation, including martime freight and } \\
\text { shipping, safety and security, and inland waterways and channels }\end{array}$ \\
\hline & & 1010 & Infrastructure & $\begin{array}{l}\text { Includes issues related to infrastructure and public works, including employment } \\
\text { intiatives }\end{array}$ \\
\hline & & 1098 & $\mathrm{R} \& \mathrm{D}$ & Includes issues related to transportation research and development \\
\hline & & 1099 & Other & Includes issues related to other transportation subtopics \\
\hline \multirow{5}{*}{12} & \multirow{5}{*}{$\begin{array}{l}\text { Includes issues related to general } \\
\text { law, crime, and family issues }\end{array}$} & 1201 & Agencies & $\begin{array}{l}\text { Includes issues related to all law enforcement agencies, including border, customs, and } \\
\text { other specialized enforcement agencies and their appropriations }\end{array}$ \\
\hline & & 1202 & White Collar Crime & $\begin{array}{l}\text { Includes issues related to white collar crime, organized crime, counterfeiting and fraud, } \\
\text { cyber-crime, and money laundering }\end{array}$ \\
\hline & & 1203 & Illegal Drugs & $\begin{array}{l}\text { Issues related to illegal drug crime and enforcement, criminal penalties for drug crimes, } \\
\text { including international efforts to combat drug trafficking }\end{array}$ \\
\hline & & 1204 & Court Administration & $\begin{array}{l}\text { Includes issues related to court administration, judiciary appropriations, guidelines for } \\
\text { bail, pre-release, fines and legal representation }\end{array}$ \\
\hline & & 1205 & Prisons & Includes issues related to prisons and jails, parole systems, and appropriations \\
\hline
\end{tabular}




\begin{tabular}{|c|c|c|c|c|}
\hline & & 1206 & Juvenile Crime & $\begin{array}{l}\text { Includes issues related to juvenile crime and justice, juvenile prisons and jails, and } \\
\text { efforts to reduce juvenile crime and recidivism }\end{array}$ \\
\hline & & 1207 & Child Abuse & $\begin{array}{l}\text { Includes issues related to child abuse, child pornography, sexual exploitation of } \\
\text { children and parental kidnapping }\end{array}$ \\
\hline & & 1208 & Family Issues & Includes issues related to family issues, domestic violence, child welfare, family law \\
\hline & & 1210 & $\begin{array}{l}\text { Criminal \& Civil } \\
\text { Code }\end{array}$ & $\begin{array}{l}\text { Includes issues related to domestic criminal and civil codes, including crimes not } \\
\text { mentioned in other subtopics }\end{array}$ \\
\hline & & 1211 & Crime Control & Includes issues related to the control, prevention, and impact of crime \\
\hline & & 1227 & Police & $\begin{array}{l}\text { Includes issues related to Police and other general domestic security responses to } \\
\text { terrorism, such as special police }\end{array}$ \\
\hline & & 1299 & Other & Includes issues related to other law, crime, and family subtopics \\
\hline & & 1302 & $\begin{array}{l}\text { Low-Income } \\
\text { Assistance }\end{array}$ & $\begin{array}{l}\text { Includes issues related to poverty assistance for low-income families, including food } \\
\text { assistance programs, programs to assess or alleviate welfare dependency and tax } \\
\text { credits directed at low income families }\end{array}$ \\
\hline & & 1303 & Elderly Assistance & $\begin{array}{l}\text { Includes issues related to elderly issues and elderly assitance, including government } \\
\text { pensions }\end{array}$ \\
\hline 13 & $\begin{array}{l}\text { Includes 1ssues generally related } \\
\text { to social welfare policy }\end{array}$ & 1304 & Disabled Assistance & Includes issues related to aid for people with physical or mental disabilities \\
\hline & & 1305 & $\begin{array}{l}\text { Volunteer } \\
\text { Associations }\end{array}$ & $\begin{array}{l}\text { Includes issues related to domestic volunteer associations, charities, and youth } \\
\text { organizations }\end{array}$ \\
\hline & & 1308 & Child Care & Includes issues related to parental leave and child care \\
\hline & & 1399 & Other & Includes issues related to other social welfare policy subtopics \\
\hline & & 1401 & $\begin{array}{l}\text { Community } \\
\text { Development }\end{array}$ & $\begin{array}{l}\text { Includes issues related to housing and community development, neighborhood } \\
\text { development, and national housing policy }\end{array}$ \\
\hline & & 1403 & Urban Development & Includes issues related to urban development and general urban issues \\
\hline & & 1404 & Rural Housing & Includes issues related to rural housing \\
\hline & & 1405 & Rural Development & Includes issues related to non-housing rural economic development \\
\hline & Includes issues related generally & 1406 & $\begin{array}{l}\text { Low-Income } \\
\text { Assistance }\end{array}$ & $\begin{array}{l}\text { Includes issues related to housing for low-income individuals and families, including } \\
\text { public housing projects and housing affordability programs }\end{array}$ \\
\hline 14 & to housing and urban affairs & 1407 & Veterans & $\begin{array}{l}\text { Includes issues related to housing for military veterans and their families, including } \\
\text { subsidies for veterans }\end{array}$ \\
\hline & & 1408 & Elderly & $\begin{array}{l}\text { Includes issues related to housing for the elderly, including housing facilities for the } \\
\text { handicapped elderly }\end{array}$ \\
\hline & & 1409 & Homeless & Includes issues related to housing for the homeless and efforts to reduce homelessness \\
\hline & & 1498 & $\mathrm{R} \& \mathrm{D}$ & $\begin{array}{l}\text { Includes issues related to housing and community development research and } \\
\text { development }\end{array}$ \\
\hline & & 1499 & Other & Other issues related to housing and community development \\
\hline & & 1501 & Banking & $\begin{array}{l}\text { Includes issues related to the regulation of national banking systems and other non- } \\
\text { bank financial institutions }\end{array}$ \\
\hline & & 1502 & $\begin{array}{l}\text { Securities \& } \\
\text { Commodities }\end{array}$ & $\begin{array}{l}\text { Includes issues related to the regulation and facilitation of securities and commodities } \\
\text { trading, regulation of investments and related industries, and exchanges }\end{array}$ \\
\hline & Includes issues generally related & 1504 & Consumer Finance & $\begin{array}{l}\text { Includes issues related to consumer finance, mortgages, credit cards, access to credit } \\
\text { records, and consumer credit fraud }\end{array}$ \\
\hline 15 & $\begin{array}{l}\text { appropriations for government } \\
\text { agencies regulating domestic }\end{array}$ & 1505 & Insurance Regulation & $\begin{array}{l}\text { Includes issues related to insurance regulation, fraud and abuse in the insurance } \\
\text { industry, the financial health of the insurance industry, and insurance availability and } \\
\text { cost }\end{array}$ \\
\hline & & 1507 & Bankruptcy & Includes issues related to personal, commercial, and municipal bankruptcies \\
\hline & & 1520 & $\begin{array}{l}\text { Corporate } \\
\text { Management }\end{array}$ & $\begin{array}{l}\text { Includes issues related to corporate mergers, antitrust regulation, corporate accounting } \\
\text { and governance, and corporate management }\end{array}$ \\
\hline & & 1521 & Small Businesses & $\begin{array}{l}\text { Includes issues related to small businesses, including programs to promote and } \\
\text { subsidize small businesses }\end{array}$ \\
\hline
\end{tabular}




\begin{tabular}{|c|c|c|c|c|}
\hline & & 1522 & $\begin{array}{l}\text { Copyrights and } \\
\text { Patents }\end{array}$ & $\begin{array}{l}\text { Includes issues related to copyrights and patents, patent reform, and intellectual } \\
\text { property }\end{array}$ \\
\hline & & 1523 & Disaster Relief & $\begin{array}{l}\text { Includes issues related to domestic natual disaster relief, disaster or flood insurance, } \\
\text { and natural disaster preparedness }\end{array}$ \\
\hline & & 1524 & Tourism & Decription: Issues related to tourism regulation, promotion, and impact \\
\hline & & 1525 & Consumer Safety & Includes issues related to consumer fraud and safety in domestic commerce \\
\hline & & 1526 & Sports Regulation & $\begin{array}{l}\text { Includes issues related to the regulation and promotion of sports, gambling, and } \\
\text { personal fitness }\end{array}$ \\
\hline & & 1598 & $\mathrm{R} \& \mathrm{D}$ & Includes issues related to domestic commerce research and development \\
\hline & & 1599 & Other & Includes issues related to other domestic commerce policy subtopics \\
\hline \multirow{17}{*}{16} & \multirow{17}{*}{$\begin{array}{l}\text { Includes issues related generally } \\
\text { to defense policy, and } \\
\text { appropriations for agencies that } \\
\text { oversee general defense policy }\end{array}$} & 1602 & Alliances & $\begin{array}{l}\text { Includes issues related to defense alliance and agreement, security assistance, and UN } \\
\text { peacekeeping activities }\end{array}$ \\
\hline & & 1603 & Intelligence & Includes issues related to military intelligence, espionage, and covert operations \\
\hline & & 1604 & Readiness & $\begin{array}{l}\text { Includes issues related to military readiness, coordination of armed services air support } \\
\text { and sealift capabilities, and national stockpiles of strategic materials. }\end{array}$ \\
\hline & & 1605 & Nuclear Arms & $\begin{array}{l}\text { Includes issues related to nuclear weapons, nuclear proliferation, modernization of } \\
\text { nuclear equipment }\end{array}$ \\
\hline & & 1606 & Military Aid & $\begin{array}{l}\text { Includes issues related to military aid to other countries and the control of arms sales } \\
\text { to other countries }\end{array}$ \\
\hline & & 1608 & Personnel Issues & $\begin{array}{l}\text { Includes issues related to military manpower, military personnel and their defendants, } \\
\text { military courts, and general veterans' issues }\end{array}$ \\
\hline & & 1610 & Procurement & $\begin{array}{l}\text { Includes issues related to military procurement, conversion of old equipment, and } \\
\text { weapons systems evaluation }\end{array}$ \\
\hline & & 1611 & Installations \& Land & Includes issues related to military installations, construction, and land transfers \\
\hline & & 1612 & Reserve Forces & Issues related to military reserves and reserve affairs \\
\hline & & 1614 & Hazardous Waste & $\begin{array}{l}\text { Includes issues related to military nuclear and hazardous waste disposal and military } \\
\text { environmental compliance }\end{array}$ \\
\hline & & 1615 & Civil & $\begin{array}{l}\text { Includes issues related to domestic civil defense, national security responses to } \\
\text { terrorism, and other issues related to homeland security }\end{array}$ \\
\hline & & 1616 & Civilian Personnel & $\begin{array}{l}\text { Includes issues related to non-contractor civilian personnel, civilian employment in the } \\
\text { defense industry, and military base closings }\end{array}$ \\
\hline & & 1617 & Contractors & $\begin{array}{l}\text { Includes issues related to military contractors and contracting, oversight of military } \\
\text { contractors and fraud by military contractors }\end{array}$ \\
\hline & & 1619 & Foreign Operations & $\begin{array}{l}\text { Includes issues related to direct war-related foreign military operations, prisoners of } \\
\text { war and collateral damage to civilian populations }\end{array}$ \\
\hline & & 1620 & $\begin{array}{l}\text { Claims against } \\
\text { Military }\end{array}$ & $\begin{array}{l}\text { Includes issues related to claims against the military, settlements for military } \\
\text { dependents, and compensation for civilizans injured in military operations }\end{array}$ \\
\hline & & 1698 & $\mathrm{R} \& \mathrm{D}$ & Includes issues related to defense research and development \\
\hline & & 1699 & Other & Includes issues related to other defense policy subtopics \\
\hline \multirow{5}{*}{17} & \multirow{5}{*}{$\begin{array}{l}\text { Includes issues related to general } \\
\text { space, science, technology, and } \\
\text { communications }\end{array}$} & 1701 & Space & $\begin{array}{l}\text { Includes issues related to the government use of space and space resource exploitation } \\
\text { agreements, government space programs and space exploration, military use of space }\end{array}$ \\
\hline & & 1704 & $\begin{array}{l}\text { Commercial Use of } \\
\text { Space }\end{array}$ & $\begin{array}{l}\text { Includes issues related to the regulation and promotion of commercial use of space, } \\
\text { commercial satellite technology, and government efforts to encourage commercial } \\
\text { space development }\end{array}$ \\
\hline & & 1705 & Science Transfer & $\begin{array}{l}\text { Includes issues related to science and technology transfer and international science } \\
\text { cooperation }\end{array}$ \\
\hline & & 1706 & Telecommunications & $\begin{array}{l}\text { Includes issues related to telephone and telecommunication regulation, infrastructure } \\
\text { for high speed internet, and other forms fo telecommunication }\end{array}$ \\
\hline & & 1707 & Broadcast & $\begin{array}{l}\text { Includes issues related to the regulation of the newspaper, publishing, radio, and } \\
\text { broadcast television industries }\end{array}$ \\
\hline
\end{tabular}




\begin{tabular}{|c|c|c|c|c|}
\hline & & 1708 & Weather Forecasting & $\begin{array}{l}\text { Includes issues related to weather forecasting, oceanography, geological surveys, and } \\
\text { weather forecasting research and technology }\end{array}$ \\
\hline & & 1709 & Computers & $\begin{array}{l}\text { Includes issues related generally to the computer industry, regulation of the internet, } \\
\text { and computer security }\end{array}$ \\
\hline & & 1798 & $R \& D$ & $\begin{array}{l}\text { Includes issues related to space, science, technology, and communication research and } \\
\text { development not mentioned in other subtopics. }\end{array}$ \\
\hline & & 1799 & Other & $\begin{array}{l}\text { Includes issues related to other space, science, technology, and communication } \\
\text { research and development }\end{array}$ \\
\hline \multirow{7}{*}{18} & \multirow{7}{*}{$\begin{array}{l}\text { Includes issues generally related } \\
\text { to foreign trade and } \\
\text { appropriations for government } \\
\text { agencies generally regulating } \\
\text { foreign trade }\end{array}$} & 1802 & Trade Agreements & $\begin{array}{l}\text { Includes issues related to trade negotiations, disputes, and agreements, including tax } \\
\text { treaties }\end{array}$ \\
\hline & & 1803 & Exports & Includes issues related to export regulation, subsidies, promotion, and control \\
\hline & & 1804 & Private Investments & $\begin{array}{l}\text { Includes issues related to international private business investment and corporate } \\
\text { development }\end{array}$ \\
\hline & & 1806 & Competitiveness & $\begin{array}{l}\text { Includes issues related to productivity of competitiveness of domestic businsses and } \\
\text { balance of payments issues }\end{array}$ \\
\hline & & 1807 & Tariff \& Imports & $\begin{array}{l}\text { Includes issues related to tariffs and other barriers to imports, import regulation and } \\
\text { impact of imports on domestic industries }\end{array}$ \\
\hline & & 1808 & Exchange Rates & Includes issues related to exchange rate and related issues \\
\hline & & 1899 & Other & Includes issues related to other foreign trade policy subtopics \\
\hline \multirow{11}{*}{19} & \multirow{11}{*}{$\begin{array}{l}\text { Includes issues related to general } \\
\text { international affairs and foreign } \\
\text { aid, including appropriations for } \\
\text { general government foreign } \\
\text { affairs agencies }\end{array}$} & 1901 & Foreign Aid & $\begin{array}{l}\text { Includes issues related to foreign aid not directly targeting at increasing international } \\
\text { development }\end{array}$ \\
\hline & & 1902 & $\begin{array}{l}\text { Resources } \\
\text { Exploitation }\end{array}$ & $\begin{array}{l}\text { Includes issues related to international resources exploitation and resources } \\
\text { agreements, law of the sea and international ocean conservation efforts }\end{array}$ \\
\hline & & 1905 & $\begin{array}{l}\text { Developing } \\
\text { Countries }\end{array}$ & $\begin{array}{l}\text { Includes issues related specifically to developing countries, developing Countries } \\
\text { Issues (for Financial Issues see 1906) }\end{array}$ \\
\hline & & 1906 & International Finance & $\begin{array}{l}\text { Includes issues related to international finance and economic development, the World } \\
\text { Bank and International Monetary Fund, regional development banks, sovereign debt } \\
\text { and implications for international lending institutions }\end{array}$ \\
\hline & & 1910 & Western Europe & Includes issues related to Western Europe and the European Union \\
\hline & & 1921 & Specific Country & $\begin{array}{l}\text { Includes issues related specifically to a foreign country or region not codable using } \\
\text { other codes, assessment of political issues in other countries, relations between } \\
\text { individual countries }\end{array}$ \\
\hline & & 1925 & Human Rights & $\begin{array}{l}\text { Includes issues related to human rights, human rights violations, human rights treaties } \\
\text { and conventions, UN reports on human rights, crimes associated with genocide or } \\
\text { crimes against humanity }\end{array}$ \\
\hline & & 1926 & Organizations & $\begin{array}{l}\text { International organizations, NGOs, the United Nations, International Red Cross, } \\
\text { UNESCO, International Olympic Committee, International Criminal Court }\end{array}$ \\
\hline & & 1927 & Terrorism & $\begin{array}{l}\text { Includes issues related to international terrorism, hijacking, and acts of piracy in other } \\
\text { countries, efforts to fight international terrorism, international legal mechanisms to } \\
\text { combat terrorism }\end{array}$ \\
\hline & & 1929 & Diplomats & $\begin{array}{l}\text { Includes issues related to diplomats, diplomacy, embassies, citizens abroad, foreign } \\
\text { diplomats in the country, visas and passports }\end{array}$ \\
\hline & & 1999 & Other & Includes issues related to other international affairs policy subtopics \\
\hline \multirow{6}{*}{20} & \multirow{6}{*}{$\begin{array}{l}\text { Includes issues related to general } \\
\text { government operations, including } \\
\text { appropriations for multiple } \\
\text { government agencies }\end{array}$} & 2001 & $\begin{array}{l}\text { Intergovernmental } \\
\text { Relations }\end{array}$ & Includes issues related to intergovernmental relations, local government issues \\
\hline & & 2002 & Bureaucracy & Includes issues related to general government efficiencies and bureaucratic oversight \\
\hline & & 2003 & Postal Service & Includes issues related to postal services, regulation of mail, and post civil service \\
\hline & & 2004 & Employees & $\begin{array}{l}\text { Includes issues related to civil employees not mentioned in other subtopics, } \\
\text { government pensions and general civil service issues }\end{array}$ \\
\hline & & 2005 & Appointments & Includes issues related to nominations and appointments not mentioned elsewhere \\
\hline & & 2006 & Currency & Includes issues related the currency, national mints, medals, and commemorative coins \\
\hline
\end{tabular}




\begin{tabular}{|c|c|c|c|c|}
\hline & & $\begin{array}{l}2007 \\
2008\end{array}$ & $\begin{array}{l}\text { Procurement \& } \\
\text { Contractors } \\
\text { Property } \\
\text { Management }\end{array}$ & $\begin{array}{l}\text { Includes issues related to government procurement, government contractors, } \\
\text { contractor and procurement fraud, and procurement processes and systems } \\
\text { Includes issues related to government property management, construction, and } \\
\text { regulation }\end{array}$ \\
\hline & & 2009 & Tax Administration & $\begin{array}{l}\text { Includes issues related to tax administration, enforcement, and auditing for both } \\
\text { individuals and corporations }\end{array}$ \\
\hline & & 2010 & Scandals & Includes issues related to public scandal and impeachment \\
\hline & & 2011 & Branch Relations & $\begin{array}{l}\text { Includes issues related to government branch relations, administrative issues, and } \\
\text { constitutional reforms }\end{array}$ \\
\hline & & 2012 & Political Campaigns & $\begin{array}{l}\text { Includes issues related to the regulation of political campaigns, campaign finance, } \\
\text { political advertising and voter registration }\end{array}$ \\
\hline & & 2013 & Census \& Statistics & Includes issues related to census and statistics collection by government \\
\hline & & 2014 & Capital City & Includes issues related to the capital city \\
\hline & & 2015 & Claims against & $\begin{array}{l}\text { Includes issues related to claims against the government, compensation for the victims } \\
\text { of terrorist attacks, compensation policies without other substantive provisions }\end{array}$ \\
\hline & & 2030 & National Holidays & Includes issues related to national holidays and their observation \\
\hline & & 2099 & Other & Includes issues related to other government operations subtopics \\
\hline \multirow{6}{*}{21} & \multirow{6}{*}{$\begin{array}{l}\text { Includes issues related to general } \\
\text { public lands, water management, } \\
\text { and terrorial issues }\end{array}$} & 2101 & National Parks & $\begin{array}{l}\text { Includes issues related to national parks, memorials, historic sites, and recreation, } \\
\text { including the management and staffing of cultural sites }\end{array}$ \\
\hline & & 2102 & Indigenous Affairs & $\begin{array}{l}\text { Includes issues related to indigenous affairs, indigenous lands, and assistance to } \\
\text { indigenous people }\end{array}$ \\
\hline & & 2103 & Public Lands & $\begin{array}{l}\text { Includes issues related to natural resources, public lands, and forest management, } \\
\text { including forest fires, livestock grazing }\end{array}$ \\
\hline & & 2104 & Water Resources & $\begin{array}{l}\text { Includes issues related to water resources, water resource development and civil works, } \\
\text { flood control, and research }\end{array}$ \\
\hline & & 2105 & $\begin{array}{l}\text { Dependencies \& } \\
\text { Territories }\end{array}$ & Includes issues related to territorial and dependency issues and devolution \\
\hline & & 2199 & Other & Includes issues related to other public lands policy subtopics \\
\hline 23 & $\begin{array}{l}\text { Includes issues related to general } \\
\text { cultural policy issues }\end{array}$ & 2300 & General & Includes issues related to general cultural policy issues \\
\hline
\end{tabular}

